\title{
Health Outcomes, Health Services Utilization, and Costs Consequences of Medicare Uninsurance among Migrants in Canada: A Systematic Review
}

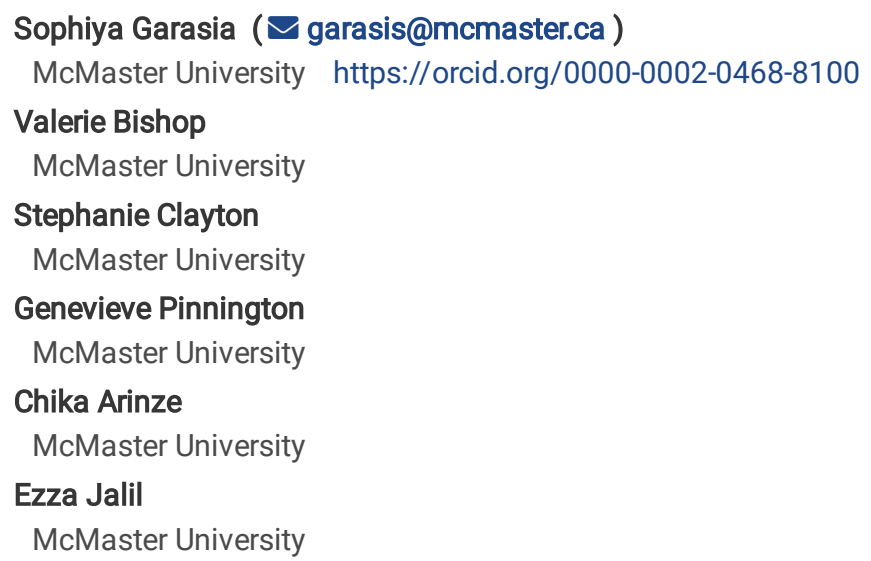

Research Article

Keywords: Migrant, Health, Medically uninsured, Health services, Canada

Posted Date: February 17th, 2022

DOI: https://doi.org/10.21203/rs.3.rs-1279298/v1

License: (c) (i) This work is licensed under a Creative Commons Attribution 4.0 International License. Read Full License 


\section{Abstract}

Background: Medically uninsured groups, many of them migrants, reportedly delay using healthcare services due to costs and often face preventable health consequences. This systematic review sought to assess quantitative evidence on health outcomes, health care utilization, and health care costs among uninsured migrant populations in Canada.

Methods: OVID MEDLINE, Embase, Global Health, EconLit, and grey literature were searched to identify relevant literature published up until March 2021. The Cochrane Risk of Bias in Non-randomized Studies - of Interventions (ROBINS-I) tool was used to assess the quality of studies.

Results: 10 studies were included. Data showed there are differences among insured and uninsured groups in reported health outcomes and healthcare use. No quantitative studies on economic costs were captured.

Conclusions: Our findings indicate a need to review policies regarding accessible and affordable health care for migrants. Increasing funding to community health centers may improve service utilization and health outcomes among this population.

\section{Background}

Despite having "universal" health coverage for physicians and hospitals in Canada, there are many residents who remain ineligible. The number of uninsured individuals is estimated to be between 200,000 to 500,000 people in Ontario alone (1); albeit, this is an underestimate given the difficulties in collecting data from this population. The impact of lack of health care insurance on medically uninsured individuals, who are mainly migrants, is an understudied area in Canada to-date (2-6).

Over 300,000 new migrants, on average, come to Canada annually and this number continues to increase (7). The United Nations Migration Agency defines a migrant as someone who is moving or has moved across an international border or within a state away from their place of birth (8). From January 2019 to March 2019, 82.0\% of Canada's population growth came from international migration (7).

Canada is well known for its publicly funded health care system, Canadian Medicare, which provides residents free access to hospital care and physician services (9). The Federal government contributes to provincial health insurance provided provinces adhere to the principles of Canada Health Act, but it is primarily the provinces in Canada that have jurisdiction over health care, including the decisions on funding and financing. However, there are exceptions - the Interim Federal Health Program (IFHP) offers temporary coverage of basic health services for refugees and asylum seekers, and the Indian Act of 1876 gives the federal government responsibility for the health care of Indigenous Peoples living on reserves. Nevertheless, some individuals are not eligible for provincial health insurance coverage due to a lack of residence status which according to the Canada Health Act principle of "universality" is a must. As the definition of "resident" is left to the provinces and territories, the eligibility criteria varies between provinces (10). In Quebec, Ontario, British Columbia, and Manitoba, a three-month waiting period is imposed on new permanent residents before they qualify for provincial health insurance (11). This policy was removed in Ontario during the Coronavirus pandemic (12) and it is unclear whether it will be reinstated. Further, undocumented and non-status migrants do not qualify for Canadian Medicare and in Ontario alone, it is estimated there are approximately 250,000 non-status migrants who do not have access to health care coverage (13).

Lack of insurance coverage can also interact with other determinants of health to influence the health and health care experiences of migrants. For example, without provincial coverage, migrants often rely on private insurance or make out-of-pocket payments which can be costly to lowincome individuals (14). Other factors including insufficient knowledge about the Canadian health care system, language barriers, fear of deportation, cultural differences, and discrimination or denial of care also generate barriers and contribute to a decline in health status ( $3,5,15$, 16).

Reduced coverage for migrants may result in an increase among patients seeking emergency care as a last resort for conditions such as uncontrolled diabetes or mental health issues that could have been addressed at earlier stages (17). Migrant families with children often experience delays in surgeries, lack of adequate care for mental health issues, and inability to access support for developmental disabilities (4). Pregnant women are also a group of concern as many go without any prenatal care and may experience complications during labour and giving birth $(4,18)$. These barriers to accessing care can lead to increased complications from untreated or delayed diagnoses of acute or chronic conditions (19). Lack of insurance coverage among migrants has been associated with lower self-perceived health (20). Literature suggests that permanent residents arrive in Canada in a healthier state than their native counterparts, but their health status deteriorates with time. This phenomenon is called "the healthy immigrant effect," and may be influenced by lack of health services usage $(21,22)$.

Reductions to IFHP in 2012, which have since been reinstated, were projected to save $\$ 50$ million per year $(19,23)$. However, a study conducted by Evans et al. (2014) found that these costs were ultimately transferred to hospitals - many of which have policies and ethical responsibilities to provide care in emergencies regardless of payment (23). For example, University Health Network in Toronto attributed over $\$ 800,000$ in unpaid service debt to uninsured emergency services as a result of IFHP changes (17). With respect to the three-month waiting period for insurance in 
Ontario, an increase in health service utilization for new permanent residents has been observed in month four (1). This suggests that individuals may be delaying necessary care until the wait period is over. Estimates from 2016 predicted that eliminating the three-month waiting period in Ontario would increase costs for the government by $\$ 60$ million (24).

Altogether there is limited understanding of the impact of Medicare uninsurance among migrants in Canada. Although challenges faced by migrants and refugees are widely known in Canada (13), at present there are limited reviews focusing on uninsured migrants and to our knowledge, no systematic reviews examining all migrant populations in Canada such as refugees, undocumented migrants, new permanent residents affected by the three month waiting period, and international students $(3,5,24)$. Previous Canadian reviews have focused on qualitative primary studies. As migration and the number of uninsured individuals increase, it is important to gain a comprehensive understanding of health outcomes and health care utilization trends among medically uninsured populations in Canada. A systematic analysis of literature can inform where there are gaps in research as well as what the priority needs are. As such, this review sought to synthesize and assess the quality of quantitative literature on health outcomes, health care utilization, and out-of-pocket expenditures and/or costs to the health care system to provide care to medically uninsured populations.

\section{Methods}

\section{Research Question and Protocol}

This systematic review asks: "What health outcomes, health care utilization trends, and health care costs are reported among uninsured migrant populations in Canada?" For the purpose of this review, uninsured populations were defined as individuals who are provincially medically uninsured (i.e., do not receive health care coverage from their province/territory for medically necessary physician and hospital services). This includes but is not limited to permanent residents waiting for their health card during the three month arrival period in certain provinces, undocumented individuals, refugees who are refused benefits under the IFHP, visitors, and international students. A systematic review protocol was created a priori to ensure transparency, reproducibility, and consistency.

\section{Search Strategy}

A comprehensive search algorithm was created and implemented in Ovid MEDLINE, EconLit, Embase, and Global Health on March 9, 2021. The algorithm was created in consultation with a university librarian, after searching "uninsured AND Canada AND health" in MEDLINE and reviewing key words in the title and abstract of relevant papers until saturation was reached. The final search algorithm consisted of key terms related to "uninsured", "health", and "Canada" and is further detailed in the supplementary document To ensure the electronic database search captured all relevant literature, reference lists from all included studies and relevant reviews were screened. In addition, targeted grey literature was searched on government and research organization websites. The first 10 pages of Google Scholar were searched on March 30,2021 using the following search terms: "uninsured AND Canada AND health".

\section{Inclusion and Exclusion Criteria}

Articles were included if they a) studied the population of interest (uninsured migrants in Canada), b) examined the intervention of interest (Medicare uninsurance), c) reported at least one outcome of interest (health outcomes, health service utilization, or health care costs), and d) reported primary quantitative data. All reviews were excluded. Other exclusion criteria included notes, editorials, books, news reports, case reports, commentaries, opinions, and letters. Studies were excluded if they focused on a migrant population residing outside of Canada. Additionally, studies examining the lack of health insurance for services not covered under Canadian Medicare, such as dental or vision care, were excluded. Due to financial and human resource limitations, studies reported in languages other than English, and French were excluded as well. Lastly, studies examining the IFHP were excluded because this federal program provides health insurance coverage for basic care services to refugees and refugee claimants, and thus does not meet the inclusion criteria.

\section{Screenings, Extraction and Quality Assessment}

Title and abstracts of papers were screened by two investigators independently using the inclusion and exclusion criteria. Disagreements were discussed and resolved between them. Full-text reviews were conducted for studies that could not be excluded on the basis of title and abstract content. Data extraction and quality assessment were conducted independently by two reviewers, and conflicts were managed by a third reviewer. Some information extracted from the studies included: year of publication, study location, demographic characteristics of the population, study design, uninsured definition, objectives of the study, outcome measures, and main results.

The Cochrane Risk of Bias in Non-randomized Studies - of Interventions (ROBINS-I) tool was used to assess the quality of included studies. The overall ratings for risk of bias were classified as low, moderate, serious, or critical. The tool was selected as it screens studies for different types of biases including selection, performance, detection, attrition, and reporting bias (25). Utilizing ROBINS-I ensured that conclusions were formed while considering the quality of the studies (25).

Review Management

Page $3 / 25$ 
Citations were imported into Covidence, an online systematic review software. The software was used for de-duplication and relevance screening to screen the titles, abstracts, and full-texts of identified articles. Five reviewers took part in the screening process. All studies were screened between March 9, 2021, and March 30, 2021. Data was extracted from relevant papers and recorded in Microsoft Excel which was also used for descriptive analysis and charting. We utilized the Preferred Reporting Items for Systematic reviews and Meta-Analyses (PRISMA) statement to guide our reporting process (26).

\section{Results}

\section{Search Results}

The search yielded 215 articles after deduplication. Of these, 134 were excluded at the title and abstract stage because they were not relevant to the topic of interest. At the full text review stage, studies failing to meet the inclusion criteria for study design, patient population, intervention, outcomes, comparator group, and setting were excluded. An additional six studies were identified through a grey literature search of Google Scholar, of which one was included. A review of the reference lists of relevant scoping reviews yielded no additional studies. Two studies used the same data but their research questions and results slightly differed, and so were extracted and reported separately $(19,20)$. A total of ten articles were included in the review. Figure 1 provides a complete overview of the study selection.

\section{Characteristics of Included Studies}

Table I shows the characteristics of included studies. Studies were conducted in the metropolitan cities of Toronto (27-31), Montreal (19, 20, 28, $31,32)$, and Vancouver (28) in the provinces of Ontario (31, 33, 34), Quebec (19, 20, 28, 31, 32), and British Columbia (28), respectively. Studies used data from 2002 to 2017, and were published between 2011 and 2020, with the majority being published in 2013 (27-29, 31). Most of the studies used chart reviews or hospital administrative data and conducted retrospective analysis (27, 29-33). Three cross-sectional studies based on questionnaires were also included $(19,20,34)$, as well as one prospective cohort study (28) using a combination of a questionnaire and administrative data. Due to the nature of study designs, longitudinal analysis was not applicable for most studies.

The definition of uninsured varied, but generally was described as individuals living in Canada who were not eligible for public health insurance either through the IFHP or provincial health insurance coverage. One study included not having private insurance as part of the definition of uninsured (20). Another identified uninsured individuals as those who were billed through the Compassionate Care Program; a program offering free primary care services to uninsured patients (27). Those who were entitled to health insurance but lacked documentation were also included as uninsured $(33,34)$. The studies altogether covered a wide scope of uninsured populations (Table I).

Studies investigated refugees or refused refugee claimants $(19,28-32)$, asylum seekers awaiting their refugee claim or those who were denied $(19,28,29,32)$, new permanent residents or immigrants $(28,29,31,34)$, visitors $(19,27,32)$, undocumented $(29,31,32)$, those with no legal or permanent migrant status $(19,27)$, foreign students and their dependents $(19,32)$, temporary foreign workers and their dependents $(19)$, those awaiting sponsorship (32), those who were self-paying and reported a permanent address (34), landed immigrants in the three month waiting period (27), those with a lost or expired health card (27), those who entered the country through non-regular means (29), and those who did not provide a reason for their uninsured status (27). Two studies provided less specific definitions for participants such as authorized and unauthorized migrants (20) and insured and uninsured (33). The number of uninsured individuals studied ranged from 52 uninsured individuals sampled from one hospital in Toronto, Ontario (27) to 140,730 uninsured individuals captured in the National Ambulatory Care Reporting System over a span of nine years (34).

In terms of sex, age, and ethnicity, most studies did not report the demographics of the uninsured population. Three studies focused on uninsured females as the objective was to assess prenatal and pregnancy outcomes and service utilization (28, 32, 35). One study focused on children exclusively (31). Only one study provided data on ethnicities of uninsured individuals (29). The study reported that the highest number of uninsured individuals were from a Caribbean background (40\%) followed by South Asian (10\%).

\section{Quality Assessment}

The overall risk of bias for the included studies ranged from low to serious (Table II). Three studies had a low risk of bias rating (19, 20, 33), six studies had a moderate rating $(27-31,34)$, and one study was rated as serious (32). Studies with a low risk of bias rating typically controlled for confounders, addressed missing data, and reported all analysis conducted. Reasoning for a moderate rating included small sample sizes, confounders not addressed, and concerns with selection bias due to the sampling methods used. Given that most studies were retrospective database or medical chart reviews, variables including socio-demographic information were often unavailable and therefore could not be controlled for. There may have been inaccuracy and inconsistency in reporting in studies using a retrospective chart review. There were also concerns with selection bias in some of the studies, especially in those sampling from non-randomly selected hospitals or clinics. One study received a serious risk of bias rating as it did not consider important confounders, used medical records that may have changed over time, did not account for missing data, did not compare those who were lost to follow up, and utilized a retrospective chart review. 
Two included cross sectional studies utilized the same population of migrants in Montreal, Quebec (19, 20). The studies differed in their purposes as Cloos et al., (2020) focused on the association between precarious migration status and self-perceived health (20) whereas Ridde et al., (2020) examined unmet health care needs and its associated factors among uninsured migrants (19). Cloos et al., (2020) reported on health outcomes (20) while Ridde et al., (2020) reported on both health outcomes and health service utilization among migrants (19) and thus we felt it necessary to include both studies in the review.

\section{Cost}

Our search did not produce any results on health care costs among the uninsured population in Canada. There were no quantitative studies that captured the out-of-pocket cost that uninsured individuals may have to pay while accessing physician or hospital services. Two studies discussed cost, however both were excluded at the data extraction stage as they examined the financial impact of the 2012 cuts to the IFHP on refugee claimants and therefore did not meet our inclusion criteria $(36,37)$. Moreover, no studies investigated the cost implications of having private insurance in the uninsured populations. This suggests a need for further research on the financial impact of health care uninsurance.

\section{Health Service Utilization}

Nine included studies reported on the impact of not having insurance on health care utilization (19, 27-34). Many of these studies concluded that utilization of health care services such as emergency room and physician visits, and hospital admissions were impeded by a lack of coverage (Table III). Two studies showed that those without insurance were more likely to initiate care when it was urgent compared to those who were insured $(31,38)$.

Most studies focused on health care services targeted towards females including prenatal and maternal care, midwifery, obstetrician access, and cervical screening. Regarding access to prenatal services, three studies reported reduced utilization among uninsured women compared to insured $(29,32,33)$. These services included prenatal visits, obstetrician services, and prenatal screening such as blood tests, cervical swabs, Pap tests, ultrasounds, and genetic screenings. Wilson-Mitchell \& Rummens (2013) found that $6.5 \%$ of uninsured women received no antenatal care, whereas $100 \%$ of the insured received care (29). Among uninsured women that received care, only $55 \%$ saw an obstetrician, compared to $94 \%$ of insured women. Uninsured women were significantly more likely to have sought the services of a midwife (36.0\% vs. $4.0 \%$ ), more likely to have presented at a later gestational age (18.4 weeks vs. 12.7 weeks) and more likely to have delivered their baby at home compared to the insured $(28.7 \%$ vs, $16.6 \%)(29,33)$. Those delivering in the hospital had shorter stays compared to insured mothers $(29,33)$. Contrary to these findings, Wiedmeyer, Lofters, \& Rashid (2012) reported that uninsured women were more likely to have had a Pap test compared to insured women $(95.0 \%$ vs. $75.0 \%$, odds ratio $(O R)=6.65 ; p<0.0001)(30)$. However, when the regression was adjusted for variables such as age and English-speaking ability, the strength of the association was not significant (OR=2.71; $95 \%$ confidence interval $(\mathrm{Cl})=0.80-9.26)$. Notably, the sample size for this retrospective chart review was small and the results may not be generalizable since it was from a health care centre that provided care specifically to uninsured individuals and had an established support system for refugees and new immigrants. Jarvis et al. (2011) studied the amount of prenatal and perinatal care accessed by uninsured pregnant women at two primary care centres, one of which provided services free of charge (32). Uninsured women had fewer prenatal visits than insured women and were more likely to have received inadequate care, which may be due to having started care later in their pregnancy. Jarvis et al. (2011) also conducted a site comparison which revealed uninsured women attended more appointments and were more likely to have received adequate care at the centre providing services free of charge (32). The results indicate that providing prenatal and perinatal care services free of charge may increase utilization among uninsured women.

The quality assessment of these studies identified limitations with selected study designs (Table II). As the majority were cross-sectional and retrospective studies, effects of temporality need to be taken into consideration when interpreting results. The reviewed data primarily originated from the emergency room and community health care centres which may not accurately represent the uninsured population in Canada. Since these centres were not randomly selected, extrapolation of the results may be misleading. Another validity concern in most of the studies is that the reported results were not adjusted for known confounders.

\section{Health Outcomes}

Table IV outlines nine studies that highlighted the impact of Medicare uninsurance on the health of Canada's migrant population (19, 20, 27-29, 31-34). Comparing results from across studies, the most common outcome reported among uninsured individuals was poor mental health. Three studies found a higher prevalence of mental and behavioural issues among the uninsured migrant population as compared to the insured $(19,20,31)$. Cloos et al. (2020) showed negative self-perceived health among migrants without health insurance versus migrants with authorized status $(\mathrm{p}<0.001)(20)$. Furthermore, the authors noted that approximately $21.0 \%$ and $70.0 \%$ of uninsured migrants reported mental distress and unmet health care needs respectively (20). The study by Cloos et al. (2020) was limited by its cross-sectional design and there may have been challenges with selection bias due to utilizing non-probability sampling (20). Moreover, Hynie et al. (2016) reported a prevalence of mental and behavioural issues at $10.5 \%$ vs. $3.5 \%$ in the uninsured and insured, respectively (34). Three studies found a total of 164 uninsured migrants with mental distress and mental health issues $(19,20,31)$. Overall, reported mental and behavioural issues were three times higher among uninsured migrant children. 
Other studies $(31,34)$ showed an association between uninsured status and adverse health outcomes (34). For example, Hynie et al. (2016) found that obstetrical complications, resuscitation, and death upon arrival to the emergency room occurred more among uninsured compared to insured individuals at $5.6 \%$ vs. $2.7 \%, 15.6 \%$ vs. $11.2 \%$, and $3.7 \%$ vs. $2.8 \%$, respectively (34). Uninsured compared to insured migrant children and youth in Ontario also showed higher diagnosis and prevalence for Ambulatory Care Sensitive Conditions at $4.6 \%$ vs. 3.2\%. Bunn et al. (2013) also found greater HIV (human immunodeficiency virus) diagnosis among uninsured patients in comparison to insured patients (24\% vs. $4 \%$ ) (27).

Apart from mental health outcomes, there was no clear relationship with one particular health outcome and insurance status. Hynie et al. (2016) reported that while injury, poor mental health, and obstetric outcomes were more frequently reported among the uninsured population, skin disease, eye disease, and respiratory conditions were more frequently reported among the insured (34). Likewise, Wilson-Mitchell et al. (2013) showed that while gestational diabetes was higher in those uninsured than insured, the opposite was true for hypertension (29). Both studies however did not test for statistical significance. Rousseau et al. (2013) tested for significance and showed that refugee claimants were significantly more frequently diagnosed with respiratory virus infections, abdominal pain, and appendicitis while uninsured children reported musculoskeletal injuries or lacerations and mental health conditions such as depression, posttraumatic stress disorder, or suicidal thoughts more often $(\chi 2=6.97 ; p=0.008)$ (31). Similar to other studies, Bunn et al. (2013) showed no statistical significant difference between the insured and uninsured groups with respect to many outcomes studied including hypertension, type 2 diabetes, and tuberculosis (27).

Four studies investigated the impact of Medicare uninsurance on maternal health outcomes including gestational age at birth, type of labour, fetal health, intrapartum and postpartum complications, and preterm birth weight among women $(28,29,32,33)$. In comparison to their insured counterparts, uninsured pregnant women were more likely to have postpartum hemorrhage (3.4\% vs. $2.9 \%)$, preterm birth (5.0\% vs. $4.4 \%)$, lower gestational age at birth (2.1\% vs. 1.7\%; 39.0 weeks vs. 39.2 weeks), and lower Caesarean section rate (35.6\% vs. 26.3\%) (32, 33). The most common reason for a Caesarean section among insured and uninsured women was labor dystocia and abnormal fetal heart rate respectively (29). Gagnon, Merry \& Haase (2013) also reported the absence of health insurance as a risk factor for higher emergency Caesarean delivery among migrant women (OR, 2.8; 95\% Cl: 1.2-6.3) (28). Uninsured women had babies with lower birth weight than insured women, but the difference was not found to be statistically significant $(29,32)$. Also, Wilson-Mitchell \& Rummens (2013) reported no significant difference between low birth rate, preterm birth, breastfeeding rates, overall maternal complications, and intrapartum medical interventions among insured and uninsured women (29). Research by Wilson-Mitchell \& Rummens (2013) (29) and Darling et al. (2019) (33) was limited by using a retrospective cohort design. Furthermore, the authors did not address nor control for confounding factors. The chart review technique utilized by Wilson-Mitchell \& Rummens (2013) also had challenges with accuracy and consistency (29). Other studies accounted for confounders where possible, however, they were limited by lack of randomization, small sample size, and potential selection bias.

Three studies reported that the determining factor behind poor health outcomes among uninsured patients was the three-month waiting period to receive health care coverage $(27,31,34)$. These studies received moderate overall bias ratings using the ROBINS-I tool. While Hynie et al. (2016) accounted for age and sex, other confounding variables such as measures of socioeconomic status were not addressed (34). Rousseau et al., 2013 did not account for confounding variables, nor did the authors address any sources of missing data (31). Finally, Bunn et al. (2013) had a small sample size which may affect generalizability of results (27). Tables I and II provide additional information on study limitations and risk of biases.

\section{Discussion}

This systematic review examined multiple databases and grey literature sources to identify studies exploring the health outcomes, utilization, and cost consequences of Medicare uninsurance among the migrant population in Canada. The results showed that the medically uninsured population is a very understudied area in Canada. Other Canadian reviews conducted with narrower inclusion criteria have reported a similar number of included studies $(3,6,28)$. Reasons for limited studies on medically uninsured populations include ethical barriers to study this population and limitations of existing data collection methods $(39,40)$. Gagnon et al $(2021)$ who conducted a narrative scoping review on immigration status as a determinant of health, which we see as a complementary study to ours, showed that studies in this area are primarily qualitative in nature (41). Our search also highlighted that literature is limited by the definition of medically uninsured. Although the inclusion criteria of the review ensured only studies researching provincially medically uninsured populations were captured, the search proved it challenging to make comparisons across all studies because of the differences in how researchers defined uninsured and insured.

Our review demonstrated a gap in Canadian quantitative literature on the medically uninsured population's out-of-pocket costs when accessing medically necessary services. There are also no economic studies that evaluate the financial impact of medically uninsured populations on the health care system. This restricts policymakers from understanding the scope of the problem. This gap should be addressed given that case studies demonstrate cost as an impeding factor to care. Caulford \& D'Andrade (2012) published a case study of an 18-year old female who was told her case was not an emergency when she visited the emergency room for her sickle cell crisis (14). While waiting in triage, she fainted and was hospitalized for 3 days, costing her $\$ 5,000$. 
Our results revealed that health services use was low when there was a lack of health insurance. For instance, some uninsured migrant women did not receive any prenatal care whatsoever (29). This is of particular concern as prenatal care is widely regarded as effective and cost-saving with research suggesting that for every \$1 US spent on prenatal care, there are \$2 of savings (42). Consistent with our findings, a scoping review by Magalhhaes et al. (2010) found that undocumented migrant workers in Canada had reduced health service utilization due to limited access to health care stemming from fear of deportation, unaffordability of services, lack of knowledge of the health care system, and social isolation (3). A study conducted by Allen et al. (2017) also reported systemic-level barriers and discrimination as a major factor behind accessing health care (43). Notably, one study in our review examined a community health centre in Toronto and found the opposite effect (30). Uninsured refugee women were more likely to receive cervical cancer screening than insured women. While rates of cervical cancer screening are low in the migrant population, this could be because the community clinic model removed barriers to care by providing interpreters, offering settlement services, and providing care to the uninsured free of cost (30). This health care model could be useful for decision-makers as an example of how to accommodate the needs of this population and provide appropriate care The same trend was observed with the use of midwives when there was a cost associated with visiting physician or hospital services that they cannot afford (29). Physicians or personal social networks may direct women towards midwifery and community health centres that are providing services at little to no cost.

The review did not provide high quality evidence on health outcomes among uninsured populations as half of the studies used descriptive analysis without measures of associations and tests of significance and without controlling for confounding factors. Our results indicated that uninsured women were at a greater risk of poor obstetric outcomes such as preterm births, emergency Caesarean sections, and postpartum hemorrhages $(28,29)$ which may be attributed to the absence of health care insurance. Moreover, new permanent residents reported mental distress, poor self-perceived health, and unmet health care needs which suggests the three-month waiting period may contribute to adverse effects on health and wellbeing (20). Consistent with previous research, a scoping review conducted on new permanent residents in Canada found the mandated three-month waiting period for health insurance created a barrier to accessing necessary care which negatively affected health outcomes (6).

Our review also revealed a greater prevalence of mental health issues such as depression and suicidal thoughts among uninsured migrants compared to their insured counterparts. Uninsured migrants often face poverty, systemic racism, trauma, lack of sufficient support systems, and added pressures when transitioning to a new environment (44). This exacerbates existing mental health issues as they cannot access services to address their needs. Similar results have been reported in other countries with high numbers of migrants with precarious status (45, 46). The growing body of qualitative Canadian studies have also reported similar findings (47). Interviews conducted by Goel et al. (2013) indicated that participants experienced emotional hardship during the three month waiting period including fear, impacting their mental health (48).

\section{Strengths and Limitations}

Our review provides a comprehensive analysis of the impact of health care uninsurance on migrants in Canada. We utilized the Cochrane ROBINS-1 Tool which allowed us to assess the quality of existing studies on the limitations of current literature. Our review has a few limitations. First, we only included studies with quantitative data. There are many qualitative studies focused on the uninsured population in Canada that could have provided interesting insights. Qualitative data may have allowed us to gain a deeper understanding of self-reported health outcomes that quantitative data do not provide. It could also explain cultural and religious beliefs regarding the use of health care, which could strengthen our understanding of the observed results. Additionally, the heterogeneity of included studies presents a limitation when interpreting results. Each study had a different definition of 'uninsured', and while some definitions shared common themes, some studies could have inadvertently included individuals who were not migrants, as chart reviews did not always include the reason for being uninsured or migratory status. We were also unable to make causal claims given the nature of the studies we included. Lastly, the review was restricted to the limits of the questions posed a priori.

\section{Implications and Future Research}

Our findings can be used to inform policy decisions regarding the provision of health insurance for migrants. Given the observed poor health outcomes, policymakers should consider how providing preventive care to migrants could be beneficial for population health and overall costs. Providing preventive care could help avoid expensive hospitalizations and improve health outcomes among the uninsured. Removing the threemonth wait period for health coverage for new permanent residents should be considered as it could improve health by providing more timely care and therefore reduce costs for the government. Further, policymakers may consider introducing more community health centres that specifically cater to migrant populations and increasing funding to existing centres as this approach appears to be successful in providing health care and improving outcomes (30). Community health centres may consider expanding their staff to include professionals specializing in mental health, pregnancy, and chronic illnesses as disparities in these areas were frequently reported in our review.

Future research may consider analyzing specific barriers that migrants face when accessing health insurance. Cost as a barrier to seeking care was not discussed in detail. This likely has a large impact on service usage as the cost of care in Canada is expensive for those who do not have insurance. Future research may consider examining the effects of removing the three month wait period in Ontario during the Coronavirus

Page $7 / 25$ 
pandemic. This would provide insight regarding the efficacy of the wait period to understand if it is cost saving overall. Moreover, our literature search revealed a lack of data on the older migrant population in Canada. The elderly often experience chronic health conditions and multiple comorbidities. It is important to investigate service utilization in this population as they require additional support from the health care system such as long-term care. Future research may also consider focusing on areas such as specific mental health issues, chronic diseases, and therapy services to better understand the burden of health care uninsurance among migrants. Lastly, included studies were primarily conducted in Ontario and Quebec which reduces generalizability of results to other provinces. British Columbia is home to a very large migrant population and yet there are minimal studies conducted in this province, and only one study included in our review $(7,28)$.

\section{Conclusion}

The review builds on existing evidence by demonstrating how lack of insurance influences health outcomes, reduces health service utilization, and inhibits access to necessary care. There is a need to provide better access to affordable health care services for the uninsured population. We hope our findings can be used to inform policy decisions with the overall goal of improving inequities in health outcomes and service usage for migrants residing in Canada.

\section{Abbreviations}

IFHP: Interim Federal Health Program

ROBINS-I: Risk of Bias in Non-randomized Studies of Interventions

PRISMA: Preferred Reporting Items for Systematic reviews and Meta-Analyses

HIV: Human Immunodeficiency Virus

OR: Odds Ratio

Cl: Confidence Interval

P: P-value

X2: Chi-squared statistic

T: T-statistic

OHIP: Ontario Health Insurance Plan

ICD: International Classification of Disease

RAMQ: Régie de l'assurance maladie du Québec

\section{Declarations}

\section{Ethics approval and consent to participate}

Ethics review was not conducted as this article is a systematic review and the research did not involve human or animal participants.

\section{Consent for publication}

Not applicable.

\section{Availability of data and materials}

All data generated or analyzed during this study are included in this published article [and its supplementary information file].

\section{Competing interests}

There are no conflicts of interest to disclose. 


\section{Funding}

This study did not receive a specific grant from any funding agency.

\section{Authors contributions}

VP, SC, GP, CA, and EZ participated in the literature search, screening, data extraction, quality assessment, interpretation of findings, and writing and editing of the manuscript. SG was involved in all parts of the project as well as conceptualizing the project and guiding the review and writing process. SG is the corresponding author. All authors have read and approved the manuscript.

\section{Acknowledgements}

We would like to thank Emmanuel Guindon for his guidance on the search strategy and scope of the study as well as his edits to the manuscript.

\section{References}

1. Barnes S. Health Care Access for the Uninsured in Ontario Symposium Report. 2016;1-12. Available from: https://www.wellesleyinstitute.com/wp-content/uploads/2017/01/Health-Care-Access-for-the-Uninsured-Symposium-Report.pdf

2. Brabant Z, Raynault MF. Health situation of migrants with precarious status: Review of the literature and implications for the Canadian context - Part A. Soc Work Public Health. 2012;27(4):330-44.

3. Magalhaes L, Carrasco C, Gastaldo D. Undocumented migrants in Canada: A scope literature review on health, access to services, and working conditions. J Immigr Minor Heal. 2010;12(1):132-51.

4. Rousseau C, Hassan G, Measham T, Lashley M. Prevalence and correlates of conduct disorder and problem behavior in Caribbean and Filipino immigrant adolescents. Eur Child Adolesc Psychiatry. 2008;17(5):264-73.

5. Salami B, Meharali S, Salami A. The health of temporary foreign workers in Canada: A scoping review. Can J Public Heal. 2015;106(8):e546-54.

6. Bobadilla A, Orchard T, Magalhães L, Fitzsimmons D. Ontario Healthcare Coverage Eligibility Among New Permanent Residents: A Scoping Review. J Immigr Refug Stud [Internet]. 2017;15(4):384-405. Available from: https://doi.org/10.1080/15562948.2016.1214993

7. Immigration Refugees and Citizenship Canada. 2020 Annual Report to Parliament on Immigration. Immigration, Refug Citizsh Canada [Internet]. 2020;41. Available from: https://www.canada.ca/en/immigration-refugees-citizenship/corporate/publications-manuals/annualreport-parliament-immigration-2020.html\#trprograms\%0Ahttps://www.canada.ca/en/immigration-refugeescitizenship/corporate/publications-manuals/annual-report-par

8. United Nations. Migration [Internet]. [cited 2021 Nov 10]. Available from: https://www.un.org/en/global-issues/migration

9. Government of Canada. Canada Health Act R.S.C., 1985, c. C-6. Canada Heal [Internet]. 1985;R.S.C C-6(2014):18. Available from: http://lawslois.justice.gc.ca

10. Allin S. Does Equity in Healthcare Use Vary across Canadian Provinces? Heal Policy. 2008;3(4):83-99.

11. Hutchison B, Levesque J, Strumpf E, Coyle N. Primary Health Care in Canada: Systems in Motion Source: The Milbank Quarterly , Vol . 89, No . 2 ( June 2011 ), pp . 256-288 Published by: Wiley on behalf of Milbank Memorial Fund Stable URL: http://www.jstor.org/stable/23036216 Your use of the JSTO. 2015;89(2):256-88.

12. Ministry of Health HSB. COVID-19 Expanding access to OHIP Coverage and Funding Physican and Hospital Services for Uninsured Patients. Info Bulletin. 2020;

13. Martin D, Miller AP, Quesnel-Vallée A, Caron NR, Vissandjée B, Marchildon GP. Canada's universal health-care system: achieving its potential. Lancet. 2018;391(10131):1718-35.

14. Caulford P, Andrade JD. Health care for Canada's medically uninsured immigrants and refugees. Can Fam Physician. 2012;58:725-7.

15. Salami B, Mason A, Salma J, Yohani S, Amin M, Okeke-Ihejirika P, et al. Access to healthcare for immigrant children in Canada. Int J Environ Res Public Health. 2020;17(9).

16. Hennebry J, McLaughlin J, Preibisch K. Out of the loop: (In)access to health care for migrant workers in Canada. J Int Migr Integr. 2015;17(2):521-38.

17. Piccininni C, Kwong M. Refugee health care funding in Canada History , current state, and future directions. 2019;1-3.

18. Khanlou N, Haque N, Mustafa N, Vazquez LM, Mantini A, Weiss J. Access Barriers to Services by Immigrant Mothers of Children with Autism in Canada. Int J Ment Health Addict. 2017;15(2):239-59. 
19. Ridde V, Aho J, Ndao EM, Benoit M, Hanley J, Lagrange S, et al. Unmet healthcare needs among migrants without medical insurance in Montreal, Canada. Glob Public Health [Internet]. 2020;15(11):1603-16. Available from: http://ovidsp.ovid.com/ovidweb.cgi? $T=J S \& P A G E=$ reference $\& D=$ med $17 \& N E W S=N \& A N=32459571$

20. Cloos P, Ndao EM, Aho J, Benoit M, Fillol A, Munoz-Bertrand M, et al. The negative self-perceived health of migrants with precarious status in Montreal, Canada: A cross-sectional study. PLoS One. 2020;15(4):1-22.

21. Ng E, Quinlan J, Giovinazzo G, Grundy A, Rank C, Syoufi M, et al. All-cause acute care hospitalization rates of immigrants and the Canadianborn population: A linkage study. Heal reports. 2021;32(9):3-13.

22. Vang ZM, Sigouin J, Flenon A, Gagnon A. Are immigrants healthier than native-born Canadians? A systematic review of the healthy immigrant effect in Canada. Ethn Heal [Internet]. 2017;22(3):209-41. Available from: http://dx.doi.org/10.1080/13557858.2016.1246518

23. Evans A, Caudarella A, Ratnapalan S, Chan K. The cost and impact of the interim federal health program cuts on child refugees in Canada. PLoS One. 2014;9(5):3-6.

24. Sanchez J, Cheff R, Hassen N, Katakia D. Part One: Examining the Health Status \& Health Care Experiences of New Permanent Residents in the Three-Month OHIP Wait A Scoping Review of the Peer-Reviewed Literature [Internet]. 2016. Available from: https://www.wellesleyinstitute.com/wp-content/uploads/2016/07/Examining-Health-in-the-Three-Month-Wait-Part-One.pdf

25. Sterne JA, Hernán MA, Reeves BC, Savović J, Berkman ND, Viswanathan M, et al. ROBINS-I: A tool for assessing risk of bias in nonrandomised studies of interventions. BMJ. 2016;355:4-10.

26. Page MJ, McKenzie JE, Bossuyt PM, Boutron I, Hoffmann TC, Mulrow CD, et al. The PRISMA 2020 statement: An updated guideline for reporting systematic reviews. BMJ. 2021;372.

27. Bunn S, Fleming P, Rzeznikiewiz D, Leung FH. Understanding the demographic characteristics and health of medically uninsured patients. Can Fam Physician. 2013;59(6).

28. Gagnon AJ, Merry L, Haase K. Predictors of emergency cesarean delivery among international migrant women in Canada. Int J Gynecol Obstet [Internet]. 2013;121(3):270-4. Available from: http://dx.doi.org/10.1016/j.ijgo.2012.12.017

29. Wilson-Mitchell K, Rummens JA. Perinatal outcomes of uninsured immigrant, refugee and migrant mothers and newborns living in Toronto, Canada. Int J Environ Res Public Health. 2013;10(6):2198-213.

30. Wiedmeyer ML, Lofters A, Rashid M. Cervical cancer screening among vulnerable women: Factors affecting guideline adherence at a community health centre in Toronto, Ont. Can Fam Physician. 2012;58(9):521-6.

31. Rousseau C, Laurin-Lamothe A, Anneke Rummens J, Meloni F, Steinmetz N, Alvarez F. Uninsured immigrant and refugee children presenting to canadian paediatric emergency departments: Disparities in help-seeking and service delivery. Paediatr Child Heal. 2013;18(9):465-9.

32. Jarvis C, Munoz M, Graves L, Stephenson R, D’Souza V, Jimenez V. Retrospective Review of Prenatal Care and Perinatal Outcomes in a Group of Uninsured Pregnant Women. J Obstet Gynaecol Canada [Internet]. 2011;33(3):235-43. Available from: http://dx.doi.org/10.1016/S1701-2163(16)34824-1

33. Darling EK, Bennett N, Burton N, Marquez O. Outcomes of uninsured midwifery clients in Ontario, Canada: A retrospective cohort study. Midwifery. 2019;77:24-31.

34. Hynie M, Ardern Cl, Robertson A. Emergency Room Visits by Uninsured Child and Adult Residents in Ontario, Canada: What Diagnoses, Severity and Visit Disposition Reveal About the Impact of Being Uninsured. J Immigr Minor Heal. 2016;18(5):948-56.

35. Mattatall FM. Uninsured Maternity Patients in Calgary: Local Trends and Survey of Health Care Workers. J Obstet Gynaecol Canada [Internet]. 2017 Nov 1;39(11):1015-20. Available from: https://doi.org/10.1016/j.jogc.2017.05.002

36. Kandasamy T, Cherniak R, Shah R, Yudin MH, Spitzer R. Obstetric Risks and Outcomes of Refugee Women at a Single Centre in Toronto. J Obstet Gynaecol Canada [Internet]. 2014;36(4):296-302. Available from: http://dx.doi.org/10.1016/S1701-2163(15)30604-6

37. Oda A, Tuck A, Agic B, Hynie M, Roche B, McKenzie K. Health care needs and use of health care services among newly arrived Syrian refugees: a cross-sectional study. C Open. 2017;5(2):E354-8.

38. Hynie M. The Social Determinants of Refugee Mental Health in the Post-Migration Context: A Critical Review. Can J Psychiatry. 2018;63(5):297-303.

39. Campbell-Page RM, Shaw-Ridley M. Managing Ethical Dilemmas in Community-Based Participatory Research With Vulnerable Populations. Health Promot Pract. 2013;14(4):485-90.

40. Samuel TJ, White PM, Perreault J. National recording systems and the measurement of international migration in Canada: an assessment. Int Migr Rev. 1987;21(4):1170-211.

41. Gagnon M, Kansal N, Goel R, Gastaldo D. Immigration Status as the Foundational Determinant of Health for People Without Status in Canada: A Scoping Review. J Immigr Minor Heal [Internet]. 2021;(0123456789). Available from: https://doi.org/10.1007/s10903-021-01273w 
42. Buescher PA, Roth MS, Williams D, Goforth CM. An evaluation of the impact of maternity care coordination on Medicaid birth outcomes in North Carolina. Am J Public Health. 1991;81(12):1625-9.

43. Allen N, Walker SR, Liberti L, Salek S. Health Technology Assessment (HTA) Case Studies: Factors Influencing Divergent HTA Reimbursement Recommendations in Australia, Canada, England, and Scotland. Value Health [Internet]. 2017;20(3):320-8. Available from: http://ovidsp.ovid.com/ovidweb.cgi?T=JS\&PAGE=reference\&D=med14\&NEWS=N\&AN=28292476

44. Kaltman S, Pauk J, Alter CL. Meeting the Mental Health Needs of Low-Income Immigrants in Primary Care: A Community Adaptation of an Evidence-Based Model. Am J Orthopsychiatry. 2011;81(4):543-51.

45. Wolff H, Stalder H, Epiney M, Walder A, Irion O, Morabia A. Health care and illegality: A survey of undocumented pregnant immigrants in Geneva. Soc Sci Med. 2005;60(9):2149-54.

46. Gushulak BD, MacPherson DW. Health issues associated with the smuggling and trafficking of migrants. [Internet]. Vol. 2, Journal of immigrant health. 2000. p. 67-78. Available from: http://www.ncbi.nlm.nih.gov/pubmed/16228734

47. Campbell RM, Klei AG, Hodges BD, Fisman D, Kitto S. A comparison of health access between permanent residents, undocumented immigrants and refugee claimants in Toronto, Canada. J Immigr Minor Heal. 2014;16(1):165-76.

48. Goel R, Bloch G, Caulford P. Waiting for care: Effects of Ontario's 3-month waiting period for OHIP on landed immigrants. Can Fam Physician. 2013;59(6):269-75.

\section{Tables}

\section{Table I}

\section{Characteristics of included studies}




\begin{tabular}{|c|c|c|c|c|c|c|}
\hline $\begin{array}{l}\text { Author \& } \\
\text { Year of } \\
\text { Publication }\end{array}$ & $\begin{array}{l}\text { Study Design } \\
\text { (Accrual) }\end{array}$ & $\begin{array}{l}\text { City and } \\
\text { Province }\end{array}$ & $\begin{array}{l}\text { Research Question / Study } \\
\text { Objectives }\end{array}$ & Data Collection & $\begin{array}{l}\text { Total } \\
\text { Sample } \\
\text { Size (n) }\end{array}$ & $\begin{array}{l}\text { Limitations } \\
\text { Reported by } \\
\text { Authors }\end{array}$ \\
\hline $\begin{array}{l}\text { Cloos, Ndao, } \\
\text { Aho, et al., } \\
(2020)\end{array}$ & $\begin{array}{l}\text { Cross- } \\
\text { sectional } \\
(2016 \text { to } \\
2017)\end{array}$ & $\begin{array}{l}\text { Montréal, } \\
\text { Québec }\end{array}$ & $\begin{array}{l}\text { To examine the association } \\
\text { between precarious } \\
\text { migration status and self- } \\
\text { perceived health in Montréal }\end{array}$ & $\begin{array}{l}\text {-Snowball sampling, } \\
\text { local media campaign } \\
\text { in community, and } \\
\text { recruitment through } \\
\text { health clinic } \\
\text {-Face-to-face } \\
\text { questionnaire } \\
\text {-Subsequent focus } \\
\text { groups }\end{array}$ & 806 & $\begin{array}{l}\text {-Potentially } \\
\text { unrepresentative } \\
\text { sample } \\
\text {-Recruiting } \\
\text { uninsured in a } \\
\text { clinic could } \\
\text { introduce } \\
\text { selection bias } \\
\text {-Self-reporting } \\
\text { could introduce } \\
\text { social desirability } \\
\text { bias } \\
\text {-Potential for } \\
\text { misreporting } \\
\text {-Lack of power } \\
\text { due to sample } \\
\text { size } \\
\text {-No control for } \\
\text { confounding } \\
\text { effects } \\
\text {-Cross-sectional } \\
\text { study design } \\
\text { makes it difficult } \\
\text { to establish } \\
\text { causality }\end{array}$ \\
\hline $\begin{array}{l}\text { Ridde, Aho, } \\
\text { Ndao, et al., } \\
(2020)\end{array}$ & $\begin{array}{l}\text { Cross- } \\
\text { sectional } \\
(2016 \text { to } \\
2017)\end{array}$ & $\begin{array}{l}\text { Montréal, } \\
\text { Québec }\end{array}$ & $\begin{array}{l}\text { To examine the unmet health } \\
\text { care needs and its } \\
\text { associated factors among } \\
\text { Medicare uninsured migrants } \\
\text { residing in Montréal }\end{array}$ & $\begin{array}{l}\text {-Snowball sampling, } \\
\text { local media campaign } \\
\text { in community, and } \\
\text { recruitment through } \\
\text { health clinic } \\
\text {-Face-to-face } \\
\text { questionnaire } \\
\text {-Subsequent focus } \\
\text { groups }\end{array}$ & 806 & $\begin{array}{l}\text {-Certain social } \\
\text { groups (Chinese } \\
\text { and Anglo- } \\
\text { Caribbean } \\
\text { migrants) were } \\
\text { underrepresented } \\
\text { - } \\
\text { Participants could } \\
\text { have been } \\
\text { surveyed twice } \\
\text { given that no } \\
\text { personal } \\
\text { information was } \\
\text { collected to } \\
\text { identify } \\
\text { participants } \\
\text {-Risk for } \\
\text { interviewer bias is } \\
\text { possible } \\
\text {-Did not collect } \\
\text { objective data } \\
\text { (such as health } \\
\text { outcomes) } \\
\text {-Cross-sectional } \\
\text { study design } \\
\text { makes it difficult } \\
\text { to establish } \\
\text { causality }\end{array}$ \\
\hline $\begin{array}{l}\text { Darling, } \\
\text { Bennett, } \\
\text { Burton, et al., } \\
(2019)\end{array}$ & $\begin{array}{l}\text { Retrospective } \\
\text { cohort (2012 } \\
\text { to 2015) }\end{array}$ & Ontario & $\begin{array}{l}\text { To analyze the } \\
\text { characteristics, health } \\
\text { service utilization, and } \\
\text { clinical outcomes of Ontario } \\
\text { residents not covered by } \\
\text { Ontario Health Insurance } \\
\text { Plan (OHIP) that receive } \\
\text { services from midwives }\end{array}$ & $\begin{array}{l}\text { - BORN-Ontario records } \\
\text { meeting criteria during } \\
\text { specified time period } \\
\text { (pregnancy to } 6 \text { weeks } \\
\text { postpartum) for all } \\
\text { midwifery clients }\end{array}$ & 55,634 & $\begin{array}{l}\text {-Did not do chi- } \\
\text { square analysis to } \\
\text { see whether the } \\
\text { proportions differ } \\
\text { by insurance } \\
\text { status } \\
\text {-BORN-Ontario } \\
\text { registry does } \\
\text { provide a reason } \\
\text { why individuals } \\
\text { are uninsured and } \\
\text { whether they had }\end{array}$ \\
\hline
\end{tabular}


non-OHIP

insurance

\begin{tabular}{|c|c|c|c|c|}
\hline $\begin{array}{l}\text { Hynie, } \\
\text { Ardern, \& } \\
\text { Robertson } \\
(2016)\end{array}$ & $\begin{array}{l}\text { Cross- } \\
\text { sectional } \\
\text { (9 } \\
\text { consecutive } \\
\text { years, } \\
2002 / 3 \text { to } \\
2010 / 11 \text { ) }\end{array}$ & Ontario & $\begin{array}{l}\text { To compare the diagnoses, } \\
\text { severity, and outcomes } \\
\text { associated with acute care } \\
\text { visits by Ontario residents } \\
\text { with and without insurance }\end{array}$ & $\begin{array}{l}\text {-Data of all emergency } \\
\text { visits in the National } \\
\text { Ambulatory Care } \\
\text { Reporting System } \\
\text { (NACRS) }\end{array}$ \\
\hline
\end{tabular}

$44,489,750$
(unique
emergency
department
visits)

-Repeat visits may have caused an increase in the

number of uninsured

$2002 / 3$ to

$\begin{array}{llll}\begin{array}{l}\text { Bunn, } \\ \text { Fleming, }\end{array} & \begin{array}{l}\text { Retrospective } \\ \text { cohort (2005 } \\ \text { Rzeznikiewiz, } \\ \text { et al., (2013) }\end{array} & \begin{array}{l}\text { Toronto, } \\ \text { Ontario }\end{array} & \begin{array}{l}\text { To determine demographic } \\ \text { and diagnostic information } \\ \text { about the medically } \\ \text { uninsured patient population } \\ \text { and compare it with that of } \\ \text { the medically insured patient } \\ \text { population at a primary care } \\ \text { centre }\end{array}\end{array}$

\begin{abstract}
-Medical charts and
billing records to

determine number of

uninsured individuals

-Random sampling used to obtain insured individuals
\end{abstract}

-Those excluded due to homelessness could have been uninsured

-NACRS data represent number of unique visits, not individuals

-Cross-sectional study design makes it difficult to establish causality

-Lack of power due to sample size

-Low external validity

-Members of uninsured group were uninsured for a number of reasons; heterogeneous group

-Unknown if al participants were screened for all of the diagnoses investigated

-No control for confounding effects

-Internal validity of this study was limited by the fact that medical charts of 7 uninsured patients and 2 insured patients could not be located

-Unclear whether the two groups are comparable in all fronts except for insurance status; only compared income, age, and sex

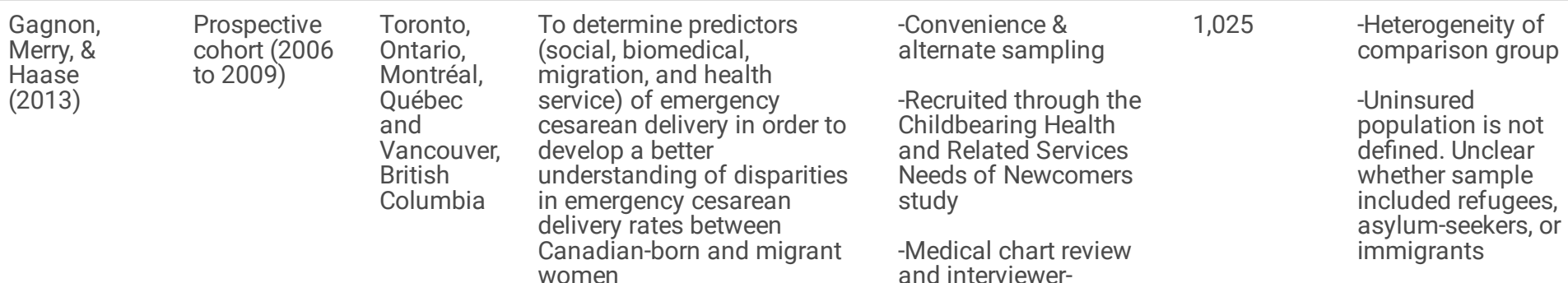

Page 13/25 
assisted validated

questionnaire
-No analysis of maternity unit characteristics

-Full regression results are not presented

-Canadian-born women were included in the original study but they did not act as a comparator here

\begin{tabular}{|c|c|c|c|}
\hline $\begin{array}{l}\text { Rousseau, } \\
\text { Laurin- } \\
\text { Lamothe, } \\
\text { Rummens, et } \\
\text { al., (2013) }\end{array}$ & $\begin{array}{l}\text { Retrospective } \\
\text { cohort } \\
(2008 \text { to } \\
2009)\end{array}$ & $\begin{array}{l}\text { Montréal, } \\
\text { Québec } \\
\text { and } \\
\text { Toronto, } \\
\text { Ontario }\end{array}$ & $\begin{array}{l}\text { To examine the differences } \\
\text { in help-seeking and service } \\
\text { delivery across migratory } \\
\text { statuses, institutions and } \\
\text { provinces }\end{array}$ \\
\hline
\end{tabular}
2009)
Ontario
-Chart review of patient records from 3 hospitals ( 2 in Montréal, 1 in Toronto)

-Charts were randomly sampled from a curated list of uninsured files Hospital 1 (Montréal) randomly selected 500 files for review

-Hospital 2 (Montréal) reviewed all files (805) without a health insurance number

-Hospital 3 (Toronto) reviewed 902 files (576 refugee claimants with IFHP coverage and 406 uninsured immigrant, refugee or undocumented patients without provincial coverage)

WilsonMitchell \& Rummens, (2013)

\section{Retrospective Toronto, cohort (2007 Ontario} to 2010)
To examine the relationship between insurance status and perinatal outcomes

\section{-Chart review of} hospital records

-Insured patients were randomly selected

-Uninsured patients were obtained from hospital record lists using self-pay payment codes
2,035

-Due to the retrospective chart review design, sociodemographic variables were unavailable or missing and could not be accounted for

-No control for confounding effects

-Potential differences across hospitals were not studied

$\begin{array}{lll}\text { Wiedmeyer, } & \text { Retrospective } & \text { Toronto, } \\ \text { Lofters, \& } & \text { cohort } & \text { Ontario }\end{array}$

Rashid,

(2012)

\section{(2004 to}

2008)
To examine if refugee women at a community health centre were appropriately screened for cervical cancer, and what characteristics affect whether they were screened
-Chart review of all patient records from the community health centre from 2004-2008 (sampling not necessary)

- Database search of all registered clients of Access Alliance
453 chart reviews may
be inaccurate or inconsistent

-Low external validity

-Lack of power due to sample size

-Researchers could not match uninsured to insured because demographic information was either inaccurate or not recorded

-Other information, such as place of birth, is not recorded in the chart

-Lack of power due to sample size

-Low external validity

-Did not analyze provider effects (such as male or 
Multicultural Health

and Community

Services meeting

criteria within the

specified timeline

\begin{tabular}{|c|c|c|c|}
\hline $\begin{array}{l}\text { Jarvis, } \\
\text { Munoz, } \\
\text { Graves, et al., } \\
(2011)\end{array}$ & $\begin{array}{l}\text { Retrospective } \\
\text { cohort } \\
\text { (2004 to } \\
2007)\end{array}$ & $\begin{array}{l}\text { Montréal, } \\
\text { Québec }\end{array}$ & $\begin{array}{l}\text { To assess prenatal and } \\
\text { perinatal health outcomes } \\
\text { among uninsured pregnant } \\
\text { women in Montréal }\end{array}$ \\
\hline
\end{tabular}

-Random sampling to

obtain insured cohort

and convenience

sampling to obtain

uninsured cohort

-Database and chart

record audit during

specified time period female physician, demeanor)

143

-Difficult

population to

study as

uninsured are

often

undocumented

-Study is not

representative of uninsured women

with no prenatal

care (low external validity)

-One of the family health centres

provided financial

assistance to

women

-Difficult to collect sociodemographic

information

-Confounders may have been missed

IFHP: Interim Federal Health Program; OHIP: Ontario Health Insurance Plan.

Table II

Risk of bias 


\begin{tabular}{|c|c|c|c|c|c|c|c|}
\hline $\begin{array}{l}\text { Author \& } \\
\text { Year of } \\
\text { Publication }\end{array}$ & $\begin{array}{l}\text { Bias due to } \\
\text { Confounding }\end{array}$ & $\begin{array}{l}\text { Bias in } \\
\text { Selection of } \\
\text { Participants } \\
\text { into the Study }\end{array}$ & $\begin{array}{l}\text { Bias in } \\
\text { Classification } \\
\text { of Interventions }\end{array}$ & $\begin{array}{l}\text { Bias due to } \\
\text { Deviations } \\
\text { from Intended } \\
\text { Interventions }\end{array}$ & $\begin{array}{l}\text { Bias due to } \\
\text { Missing } \\
\text { Data }\end{array}$ & $\begin{array}{l}\text { Bias in } \\
\text { Measurement } \\
\text { of Outcomes }\end{array}$ & $\begin{array}{l}\text { Bias in } \\
\text { Selection } \\
\text { of the } \\
\text { Reported } \\
\text { Result }\end{array}$ \\
\hline \multirow{2}{*}{$\begin{array}{l}\text { Cloos, Ndao, } \\
\text { Aho, et al., } \\
(2020) \\
\text { Overall bias: } \\
\text { Low }\end{array}$} & Low & Low & Low & Low & Low & Low & Low \\
\hline & $\begin{array}{l}\text { Multivariate } \\
\text { regression } \\
\text { conducted and } \\
\text { controlled for } \\
\text { many variables. }\end{array}$ & $\begin{array}{l}\text { Non- } \\
\text { probability } \\
\text { sampling at a } \\
\text { clinic was } \\
\text { employed to } \\
\text { recruit } \\
\text { uninsured } \\
\text { which may } \\
\text { have } \\
\text { introduced } \\
\text { selection bias. } \\
\text { Bias reduced } \\
\text { by also } \\
\text { recruiting } \\
\text { from venue- } \\
\text { based } \\
\text { sampling and } \\
\text { social media. }\end{array}$ & $\begin{array}{l}\text { Clear definition } \\
\text { for uninsured. }\end{array}$ & $\begin{array}{l}\text { Study } \\
\text { conducted } \\
\text { around the time } \\
\text { of Interim } \\
\text { Federal Health } \\
\text { Program (IFHP) } \\
\text { reinstatement } \\
\text { which was not } \\
\text { addressed. } \\
\text { Individuals who } \\
\text { were unaware } \\
\text { that they were } \\
\text { eligible for the } \\
\text { IFHP or who } \\
\text { had benefited } \\
\text { from it in the } \\
\text { past but had } \\
\text { not been able } \\
\text { to extend or } \\
\text { renew it were } \\
\text { also included. } \\
\text { Excluded those } \\
\text { with private } \\
\text { insurance or } \\
\text { IFHP. }\end{array}$ & $\begin{array}{l}\text { Little } \\
\text { missing } \\
\text { data - did } \\
\text { not exceed } \\
5 \% \text { for } \\
\text { most } \\
\text { variables } \\
\text { and for the } \\
\text { three } \\
\text { variables } \\
\text { that had } \\
12 \% \text {, they } \\
\text { were } \\
\text { excluded. }\end{array}$ & $\begin{array}{l}\text { Questionnaire } \\
\text { was developed } \\
\text { using the } \\
\text { Trajectory } \\
\text { Model and } \\
\text { was validated } \\
\text { in migrant and } \\
\text { general } \\
\text { populations. } \\
\text { Questionnaire } \\
\text { was available } \\
\text { in multiple } \\
\text { languages. } \\
\text { May have } \\
\text { limited } \\
\text { interviewer } \\
\text { bias given that } \\
\text { research } \\
\text { assistants } \\
\text { knew that they } \\
\text { were } \\
\text { interviewing } \\
\text { uninsured } \\
\text { individuals. } \\
\text { The outcome } \\
\text { was self- } \\
\text { reported. }\end{array}$ & $\begin{array}{l}\text { Reported } \\
\text { all analysis } \\
\text { conducted. }\end{array}$ \\
\hline $\begin{array}{l}\text { Ridde, Aho, } \\
\text { Ndao, et al., } \\
(2020)\end{array}$ & Low & Low & Low & Low & Low & Low & Low \\
\hline $\begin{array}{l}\text { (2020) } \\
\text { Overall bias: } \\
\text { Low }\end{array}$ & $\begin{array}{l}\text { Multivariate } \\
\text { regression } \\
\text { conducted and } \\
\text { controlled for } \\
\text { many variables. }\end{array}$ & $\begin{array}{l}\text { Non- } \\
\text { probability } \\
\text { sampling at a } \\
\text { clinic was } \\
\text { employed to } \\
\text { recruit } \\
\text { uninsured } \\
\text { which may } \\
\text { have } \\
\text { introduced } \\
\text { selection bias. } \\
\text { Bias reduced } \\
\text { by also } \\
\text { recruiting } \\
\text { from venue- } \\
\text { based } \\
\text { sampling and } \\
\text { social media. }\end{array}$ & $\begin{array}{l}\text { Clear definition } \\
\text { of uninsured. }\end{array}$ & $\begin{array}{l}\text { Study } \\
\text { conducted } \\
\text { around the time } \\
\text { of IFHP } \\
\text { reinstatement } \\
\text { which was not } \\
\text { addressed. } \\
\text { Individuals who } \\
\text { were unaware } \\
\text { that they were } \\
\text { eligible for the } \\
\text { IFHP or who } \\
\text { had benefited } \\
\text { from it in the } \\
\text { past but had } \\
\text { not been able } \\
\text { to extend or } \\
\text { renew it were } \\
\text { also included. } \\
\text { Excluded those } \\
\text { with private } \\
\text { insurance or } \\
\text { IFHP. }\end{array}$ & $\begin{array}{l}\text { Little } \\
\text { missing } \\
\text { data - did } \\
\text { not exceed } \\
5 \% \text { for } \\
\text { most } \\
\text { variables } \\
\text { and for the } \\
\text { three } \\
\text { variables } \\
\text { that had } \\
12 \% \text {, they } \\
\text { were } \\
\text { excluded. }\end{array}$ & $\begin{array}{l}\text { Questionnaire } \\
\text { was developed } \\
\text { using the } \\
\text { Trajectory } \\
\text { Model and } \\
\text { was validated } \\
\text { in migrant and } \\
\text { general } \\
\text { populations. } \\
\text { Questionnaire } \\
\text { was available } \\
\text { in multiple } \\
\text { languages. } \\
\text { May have } \\
\text { limited } \\
\text { interviewer } \\
\text { bias given that } \\
\text { research } \\
\text { assistants } \\
\text { knew that they } \\
\text { were } \\
\text { interviewing } \\
\text { uninsured } \\
\text { individuals. } \\
\text { The outcome } \\
\text { was self- } \\
\text { reported. }\end{array}$ & $\begin{array}{l}\text { Reported } \\
\text { all analysis } \\
\text { conducted. }\end{array}$ \\
\hline Darling, & Moderate & Low & Moderate & Low & Low & Low & Low \\
\hline $\begin{array}{l}\text { Burton, et al., } \\
\text { (2019) } \\
\text { Overall bias: } \\
\text { Low }\end{array}$ & $\begin{array}{l}\text { Potential for } \\
\text { confounders that } \\
\text { were not } \\
\text { measured and not } \\
\text { controlled for in } \\
\text { the analysis (little } \\
\text { information } \\
\text { regarding } \\
\text { sociodemographic } \\
\text { factors, missing } \\
\text { parity or maternal } \\
\text { age). }\end{array}$ & $\begin{array}{l}\text { Population- } \\
\text { based cohort } \\
\text { of all } \\
\text { midwifery } \\
\text { clients who } \\
\text { gave birth } \\
\text { between } 2012 \\
\text { and } 2015 \text {. }\end{array}$ & $\begin{array}{l}\text { BORN-Ontario } \\
\text { registry does } \\
\text { not detail why } \\
\text { participants } \\
\text { were uninsured. } \\
\text { They defined } \\
\text { intervention } \\
\text { group to be } \\
\text { those that did } \\
\text { not have } \\
\text { Ontario Health } \\
\text { Insurance Plan } \\
\text { (OHIP) and } \\
\text { comparator }\end{array}$ & $\begin{array}{l}\text { Excluded those } \\
\text { whose } \\
\text { insurance } \\
\text { status was } \\
\text { unclear. }\end{array}$ & $\begin{array}{l}\text { BORN- } \\
\text { Ontario had } \\
\text { high } \\
\text { completion } \\
\text { of data. }\end{array}$ & $\begin{array}{l}\text { Study used } \\
\text { retrospective } \\
\text { BORN-Ontario } \\
\text { administrative } \\
\text { data which } \\
\text { had validation } \\
\text { checks, but } \\
\text { retrospective } \\
\text { chart review is } \\
\text { problematic } \\
\text { due to } \\
\text { inaccuracy } \\
\text { and }\end{array}$ & $\begin{array}{l}\text { Reported } \\
\text { all analysis } \\
\text { conducted } \\
\text { and } \\
\text { numbers of } \\
\text { individuals } \\
\text { excluded. } \\
\text { The } \\
\text { numbers in } \\
\text { the text are } \\
\text { not the } \\
\text { same as } \\
\text { those } \\
\text { reported in }\end{array}$ \\
\hline
\end{tabular}




\begin{tabular}{|c|c|c|c|c|c|c|c|}
\hline & & & $\begin{array}{l}\text { group to be } \\
\text { those with } \\
\text { OHIP. }\end{array}$ & & & $\begin{array}{l}\text { inconsistency } \\
\text { in recording. }\end{array}$ & $\begin{array}{l}\text { the tables. } \\
\text { Confidence } \\
\text { intervals } \\
\text { are not } \\
\text { reported. }\end{array}$ \\
\hline \multirow{2}{*}{$\begin{array}{l}\text { Hynie, } \\
\text { Ardern, \& } \\
\text { Robertson } \\
(2016) \\
\\
\text { Overall bias: } \\
\text { Moderate }\end{array}$} & Moderate & Moderate & Low & Moderate & Moderate & Moderate & Low \\
\hline & $\begin{array}{l}\text { Potential for } \\
\text { confounders that } \\
\text { were not } \\
\text { measured and not } \\
\text { controlled for (age } \\
\text { and sex were } \\
\text { adjusted for but } \\
\text { socioeconomic } \\
\text { factors were not). }\end{array}$ & $\begin{array}{l}\text { Administrative } \\
\text { dataset used. } \\
\text { Looked at } \\
\text { main } \\
\text { diagnoses for } \\
\text { insured and } \\
\text { uninsured } \\
\text { clients in a } \\
10 \% \\
\text { subsample- } \\
\text { how they } \\
\text { selected them } \\
\text { not specified. }\end{array}$ & $\begin{array}{l}\text { Analysis of } 9 \\
\text { consecutive } \\
\text { years of data } \\
\text { reduced the } \\
\text { impact of } \\
\text { temporality. } \\
\text { Uninsured } \\
\text { definition as } \\
\text { those who were } \\
\text { self-paying. } \\
\text { Reason for self- } \\
\text { paying not } \\
\text { addressed. }\end{array}$ & $\begin{array}{l}\text { People would } \\
\text { only pay out-of- } \\
\text { pocket or pay } \\
\text { through } \\
\text { insurance. } \\
\text { Unclear } \\
\text { whether people } \\
\text { had private } \\
\text { insurance and } \\
\text { would get } \\
\text { reimbursed } \\
\text { later. }\end{array}$ & $\begin{array}{l}\text { Not } \\
\text { addressed. }\end{array}$ & $\begin{array}{l}\text { International } \\
\text { Classification } \\
\text { of Diseases } \\
\text { (ICD) codes } \\
\text { may have } \\
\text { differed across } \\
\text { the } 9 \text { years as } \\
\text { not all } \\
\text { hospitals } \\
\text { adopted it in } \\
\text { 2002. The } \\
\text { software was } \\
\text { assessed and } \\
\text { said to be } \\
\text { valid but there } \\
\text { was under- } \\
\text { reporting of } \\
\text { multiple } \\
\text { problems and } \\
\text { lower } \\
\text { agreement of } \\
\text { main problem } \\
\text { for those with } \\
\text { multiple } \\
\text { problems. }\end{array}$ & $\begin{array}{l}\text { Reported } \\
\text { all analysis } \\
\text { conducted. } \\
\text { Did not } \\
\text { report } p \text { - } \\
\text { values and } \\
\text { confidence } \\
\text { intervals } \\
\text { for all } \\
\text { analysis. }\end{array}$ \\
\hline \multirow{2}{*}{$\begin{array}{l}\text { Bunn, } \\
\text { Fleming, } \\
\text { Rzeznikiewiz, } \\
\text { et al., (2013) } \\
\text { Overall bias: } \\
\text { Moderate }\end{array}$} & Serious & Moderate & Low & Moderate & Moderate & Moderate & Low \\
\hline & $\begin{array}{l}\text { Study was } \\
\text { descriptive - no } \\
\text { modelling } \\
\text { conducted. No } \\
\text { covariates } \\
\text { controlled for. }\end{array}$ & $\begin{array}{l}\text { Small sample } \\
\text { size. Had a } \\
\text { 1:1 case to } \\
\text { control ratio. } \\
\text { Did not } \\
\text { describe } \\
\text { randomization } \\
\text { process for } \\
\text { selecting } \\
\text { controls-Case } \\
\text { and controls } \\
\text { were different } \\
\text { in median } \\
\text { income. }\end{array}$ & $\begin{array}{l}\text { A lot of the } \\
\text { uninsured } \\
\text { population did } \\
\text { not provide } \\
\text { reason for } \\
\text { being } \\
\text { uninsured so } \\
\text { unclear why } \\
\text { they billed } \\
\text { Compassionate } \\
\text { Care Program. }\end{array}$ & $\begin{array}{l}\text { Unclear } \\
\text { whether all } \\
\text { those who } \\
\text { billed through } \\
\text { Compassionate } \\
\text { Care Program } \\
\text { had no form of } \\
\text { insurance. }\end{array}$ & $\begin{array}{l}\text { Uninsured } \\
\text { had greater } \\
\text { amount of } \\
\text { missing } \\
\text { charts and } \\
\text { had } \\
\text { missing } \\
\text { information } \\
\text { on income. }\end{array}$ & $\begin{array}{l}\text { Researchers } \\
\text { were unsure if } \\
\text { every } \\
\text { participant } \\
\text { was screened } \\
\text { for all of the } \\
\text { diagnoses } \\
\text { investigated. } \\
\text { Retrospective } \\
\text { chart reviews } \\
\text { are } \\
\text { problematic } \\
\text { due to } \\
\text { inaccuracy } \\
\text { and } \\
\text { inconsistency } \\
\text { in recording. }\end{array}$ & $\begin{array}{l}\text { Reported } \\
\text { all analysis } \\
\text { conducted. }\end{array}$ \\
\hline \multirow{2}{*}{$\begin{array}{l}\text { Gagnon, } \\
\text { Merry, \& } \\
\text { Haase } \\
(2013) \\
\text { Overall bias: } \\
\text { Moderate }\end{array}$} & Low & Low & Moderate & Moderate & Moderate & Low & Moderate \\
\hline & $\begin{array}{l}\text { Several } \\
\text { confounding } \\
\text { variables were } \\
\text { controlled for. } \\
\text { Used regression } \\
\text { modelling. }\end{array}$ & $\begin{array}{l}\text { Sampled from } \\
12 \text { hospitals. } \\
\text { Selected } \\
\text { individuals } \\
\text { from set } \\
\text { categories } \\
\text { and selected } \\
\text { controls with } \\
\text { closest date } \\
\text { and date of } \\
\text { birth to a } \\
\text { case. }\end{array}$ & $\begin{array}{l}\text { Used pre-set } \\
\text { definitions to } \\
\text { identify } \\
\text { refugees, } \\
\text { asylum } \\
\text { seekers, and } \\
\text { immigrants. } \\
\text { Did not } \\
\text { describe health } \\
\text { insurance } \\
\text { variable. }\end{array}$ & $\begin{array}{l}\text { Study was } \\
\text { before cuts } \\
\text { made to IFHP. } \\
\text { Whether } \\
\text { uninsured had } \\
\text { federal } \\
\text { insurance or } \\
\text { private } \\
\text { insurance was } \\
\text { unclear. }\end{array}$ & $\begin{array}{l}\text { Reduced } \\
\text { model } \\
\text { presented } \\
\text { when data } \\
\text { was } \\
\text { missing. } \\
\text { Did not } \\
\text { investigate } \\
\text { missing } \\
\text { data } \\
\text { further. }\end{array}$ & $\begin{array}{l}\text { Obtained data } \\
\text { prospectively } \\
\text { through } \\
\text { interviews as } \\
\text { well as } \\
\text { medical } \\
\text { records. } \\
\text { Questionnaires } \\
\text { were available } \\
\text { in multiple } \\
\text { languages. } \\
\text { Data } \\
\text { verification } \\
\text { protocol was } \\
\text { utilized. }\end{array}$ & $\begin{array}{l}\text { Did not } \\
\text { present full } \\
\text { regression } \\
\text { results. }\end{array}$ \\
\hline \multirow{2}{*}{$\begin{array}{l}\text { Rousseau, } \\
\text { Laurin- } \\
\text { Lamothe, } \\
\text { Rummens, et } \\
\text { al., (2013) } \\
\text { Overall bias: } \\
\text { Moderate }\end{array}$} & Moderate & Moderate & Low & Moderate & Moderate & Moderate & Low \\
\hline & $\begin{array}{l}\text { Sociodemographic } \\
\text { information was } \\
\text { not reported. } \\
\text { Potential for } \\
\text { confounders that } \\
\text { were not } \\
\text { measured and not } \\
\text { controlled for. }\end{array}$ & $\begin{array}{l}\text { The hospitals } \\
\text { involved in the } \\
\text { study were not } \\
\text { randomly } \\
\text { selected. The } \\
\text { hospitals } \\
\text { differed from } \\
\text { one another in }\end{array}$ & $\begin{array}{l}\text { Uninsured were } \\
\text { those who } \\
\text { didn't have } \\
\text { OHIP or Régie } \\
\text { de l'assurance } \\
\text { maladie du } \\
\text { Québec } \\
\text { (RAMQ) as }\end{array}$ & $\begin{array}{l}\text { Did not exclude } \\
\text { those who may } \\
\text { have private } \\
\text { insurance or } \\
\text { IFHP. }\end{array}$ & $\begin{array}{l}\text { Not } \\
\text { addressed. }\end{array}$ & $\begin{array}{l}\text { Hospitals } \\
\text { differed in } \\
\text { their record- } \\
\text { keeping. One } \\
\text { hospital in } \\
\text { particular had } \\
\text { a migrant } \\
\text { outpatient and }\end{array}$ & $\begin{array}{l}\text { Reported } \\
\text { all analysis } \\
\text { conducted. }\end{array}$ \\
\hline
\end{tabular}




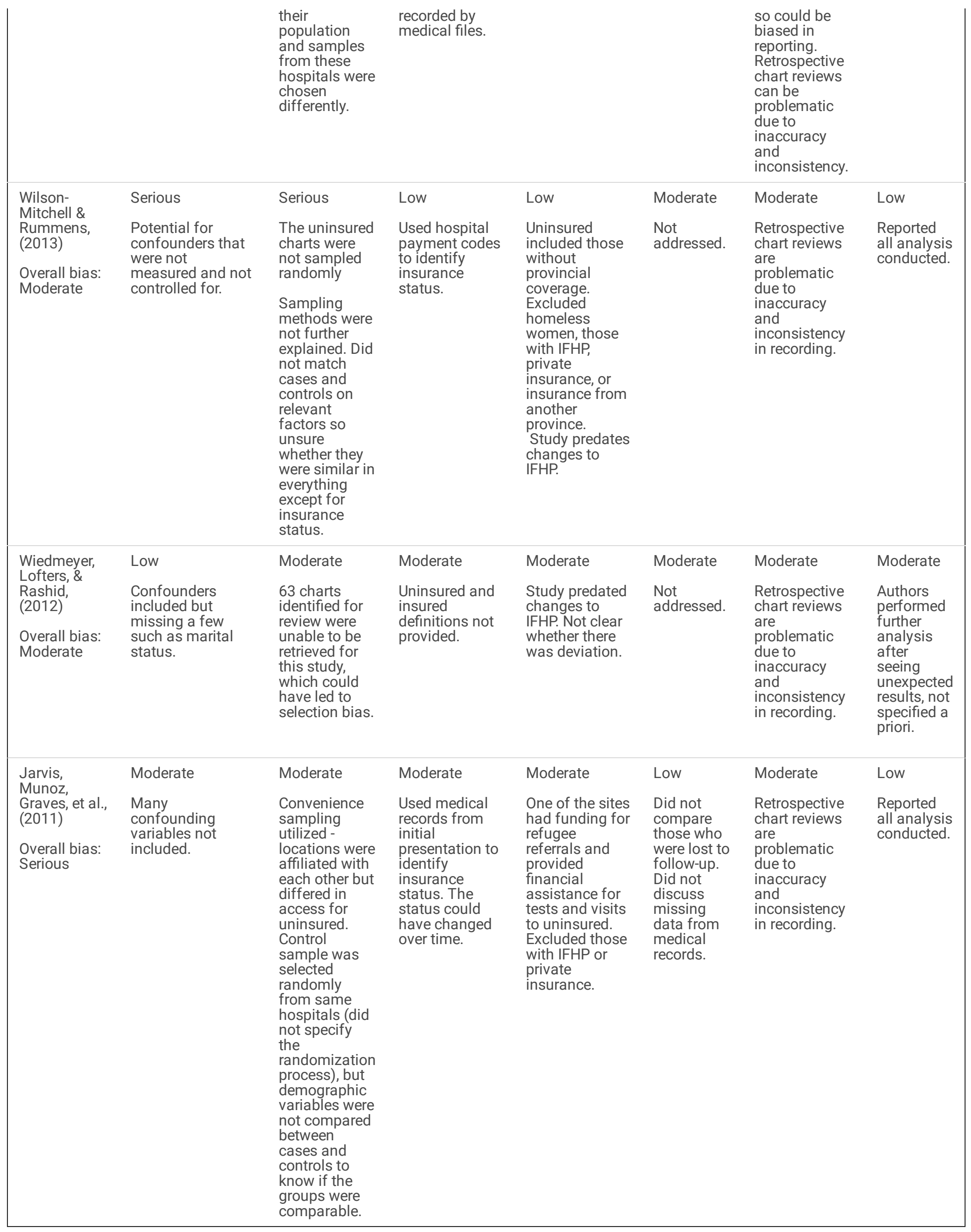


IFHP: Interim Federal Health Program; OHIP: Ontario Health Insurance Plan; ICD: International Classification of Disease; RAMQ: Régie de l'assurance maladie du Québec

Table III

Health service utilization of uninsured population

Page 19/25 


\begin{tabular}{|c|c|c|}
\hline $\begin{array}{l}\text { Author \& } \\
\text { Year of } \\
\text { Publication }\end{array}$ & Service Accessed & Main Results \\
\hline $\begin{array}{l}\text { Ridde, Aho, } \\
\text { Ndao, et al., } \\
(2020)\end{array}$ & $\begin{array}{l}\text {-Private pharmacies } \\
\text {-Community organized } \\
\text { health clinics } \\
\text {-Walk-in clinics } \\
\text {-Dental clinics } \\
\text {-Hospitals }\end{array}$ & $\begin{array}{l}\text {-Unreported health care needs were reported by } 69 \% \text { of uninsured migrants in comparison } \\
\text { to } 26 \% \text { of recent immigrants and } 16 \% \text { of citizens with insurance. Unmet health care needs } \\
\text { were greatest among temporary workers and their descendants }(73 \%) \text {. } \\
\text {-The association between unmet health care needs and migrant status was not statistically } \\
\text { significant. } \\
\text {-Reasons for unmet health care needs included not having enough money to pay fees } \\
\text { ( } 81 \%) \text {, fear of being overcharged ( } 73 \%) \text {, potential negative impact of health consultation on } \\
\text { migration status ( } 22 \%) \text {, and fear of rejection by hospital ( } 7 \%) \text {. } \\
\text {-Almost one fifth ( } 19 \%) \text { of all participants reported not knowing where to access health } \\
\text { care. } \\
\text {-Among those who used health care services, they accessed private pharmacies }(60 \%), \\
\text { community organized health services ( } 43 \%), \text { walk-in-clinics }(21 \%) \text {, dental clinics }(16 \%), \text { and } \\
\text { hospitals }(14 \%) \text {. } \\
\text {-Services such as osteopathy, chiropractic, and physiotherapy were used by less than } 3 \% \text {. }\end{array}$ \\
\hline $\begin{array}{l}\text { Darling, } \\
\text { Bennett, } \\
\text { Burton, et al., } \\
\text { (2019) }\end{array}$ & $\begin{array}{l}\text {-Antenatal services } \\
\text {-Intrapartum services } \\
\text {-Postpartum services }\end{array}$ & $\begin{array}{l}\text {-Uninsured migrant women compared to insured women: } \\
\text {-Attended fewer antenatal appointments (mean } 9.9 \text { visits vs. } 11.6 \text { visits). } \\
\text {-Had more antenatal home visits (mean } 1.9 \text { visits vs. } 0.6 \text { visits). } \\
\text {-Were less likely to attend a prenatal visit in the first trimester ( } 66.3 \% \text { vs. } 92.8 \% \text { ). } \\
\text {-Presented later to midwifery care ( } 18.4 \text { weeks gestation vs. } 12.7 \text { weeks gestation). } \\
\text {-Were less likely to attend prenatal class ( } 33.2 \% \text { vs. } 65.2 \% \text { for primiparous participants and } \\
2.9 \% \text { vs. } 5.7 \% \text { for multiparous participants). } \\
\text {-Had shorter hospital stays when they gave birth at the hospital (median } 2 \text { hours vs. } 3 \\
\text { hours). } \\
\text {-Had more intrapartum consultations for fetal well-being and meconium while } \\
\text { consultations for labour dystocia, oxytocin augmentation, and epidural were less common. } \\
\text {-Received more postpartum home visits (mean } 3.7 \text { visits vs. } 3.2 \text { visits). } \\
\text { - Planned for home birth more ( } 33.9 \% \text { planned home birth and } 28.7 \% \text { gave birth at home } \\
\text { whereas } 19.6 \% \text { insured planned home birth and } 16.6 \% \text { gave birth at home). } \\
\text {-Were less likely to have at least one postpartum consultation with a physician ( } 5.5 \% \text { vs. } \\
6.8 \% \text { ). } \\
\text {-Were more likely to have a registered midwife ( } 64.7 \% \text { vs. } 60.2 \%) \text {. } \\
\text {-Had lower transfer of care in labour (6.1\% vs. } 23.8 \% \text { ). } \\
\text {-Had lower newborn intensive care unit admissions ( } 8.7 \% \text { vs. } 9.2 \% \text { ). } \\
\text {-Had lower newborn metabolic screening ( } 90.9 \% \text { vs. } 92 \% \text { ). } \\
\text {-Had lower severity in care level. Level } 1 \text { hospitals were low-need and level } 3 \text { hospitals were } \\
\text {-The proportion of uninsured clients varied across the province, with midwifery clinics in the } \\
\text { South West, Central, and Toronto Central Local Health Integration Networks caring for the } \\
\text { highest percentage of uninsured clients. }\end{array}$ \\
\hline $\begin{array}{l}\text { Hynie, } \\
\text { Ardern, \& } \\
\text { Robertson } \\
\text { (2016) }\end{array}$ & $\begin{array}{l}\text {-Emergency room } \\
\text {-Hospital }\end{array}$ & $\begin{array}{l}\text {-The percentage of visits of uninsured increased from } 0.23 \% \text { in } 2002 / 3 \text { to } 0.44 \% \text { in } \\
2010 / 11 . \\
\text {-Within Ontario, the proportion of visits by the uninsured to the emergency room ranged } \\
\text { from } 0.07 \% \text { in Erie St. Clair to } 0.66 \% \text { in Toronto. } \\
\text {-Visit disposition differed by insurance status as those without insurance were less likely to } \\
\text { be admitted ( } 10.2 \% \text { insured vs. } 9.4 \% \text { uninsured), more likely to leave without treatment } \\
\text { (3.1\% insured vs. } 5.4 \% \text { uninsured), and more likely to have died on arrival or in the } \\
\text { emergency room ( } 2.8 \% \text { insured vs. } 3.7 \% \text { uninsured). } \\
\text {-Emergency room visits related to ambulatory care sensitive conditions were more common } \\
\text { among the insured than uninsured ( } 4.55 \% \text { vs. } 3.18 \%) \text {. } \\
\text {-A larger proportion of ambulatory care sensitive condition visits were accounted for by } \\
\text { children ( } \leq 16 \text { years), and youth ( } 17-24 \text { years) in the uninsured group. }\end{array}$ \\
\hline
\end{tabular}

Page 20/25 
-Insured and uninsured were equally likely to be triaged into one of the severe categories if they arrived with ambulatory care sensitive conditions.

-At hospital presentation, $15.6 \%$ of uninsured and $11.2 \%$ of insured individuals were triaged into one of the more severe categories (resuscitation or emergent).

-Compared to insured individuals (Odds Ratio (OR(1.00, referent), those who were uninsured were $43 \%$ more likely (OR 1.43; $95 \%$ Confidence Interval (CI): 1.39-1.46) to be classified as severe, even after adjustment for age and gender.

Bunn, -Prenatal care

Fleming,

Rzeznikiewiz, -Pediatric care

et al., (2013)
-No significant difference between participants with Ontario Health Insurance Plan vs. participants utilizing the Compassionate Care Program in the proportion of patients seeking prenatal or routine pediatric care.

$-6 \%$ and $16 \%$ of insured and uninsured used prenatal care, respectively ( $p$ value $(p)=0.184$ ).

$-18 \%$ and $11 \%$ of insured and uninsured used routine pediatric care, respectively $(p=0.344)$.

Gagnon, -Newborn intensive care unit Merry, \& admission

-Significant differences in newborn intensive care unit admission were found among refugees $(26.7 \%)$, asylum seekers $(15.6 \%)$ and immigrants $(7.0 \%)$, where $p=0.073$.

Haase -Hospital

Rousseau, -Emergency room

Laurin-

Lamothe,

Rummens, et

al., (2013)

$-1.3 \%$ of uninsured children compared to $0.3 \%$ of federally insured refugee children had the highest level of emergency (level 1) (chi-squared statistic $\left(x^{2}\right)=15,290.01 ; p<0.001$ ) and $11.5 \%$ of uninsured children vs. $8.5 \%$ of federally insured refugee children had the second highest level of emergency (level 2$)\left(x^{2}=89,055.93 ; p<0.001\right)$. For levels $3-5$, there were no significant differences between groups.

-In hospitals 2 (Montreal) $(t=4.81 ; p<0.001)$ and 3 (Toronto) (t statistic $(t)=6.83 ; p<0.001$ ) the mean emergency rating at triage for uninsured immigrant and refugee claimant children was significantly higher (less urgent) than the mean emergency rating of the overall hospital populations.

-In hospital 1 (Montreal), the refugee claimant and uninsured children status mean emergency rating was comparable with the overall hospital population mean emergency rating $(t=-1.62 ; p=0.105)$.

-Hospitalization of refugee claimants was more frequent in hospital 1 (25.1\%) in Montreal compared to hospital $2(2.5 \%)$ in Montreal and hospital $3(9.2 \%)$ in Toronto [ $p<0.001]$.

-In hospital 2 (Montreal), $82.6 \%$ of children were prescribed medication, compared with $55.7 \%$ in hospital 3 (Toronto) and 34.3\% in hospital 1 (Montreal) ( $p<0.001$ ).

-In both hospital 1 and hospital 3, the overall number of children leaving with another follow-up plan documented in the file was approximately $20 \%$; in contrast, it was $2.0 \%$ in hospital 2 , where $10.6 \%$ of children also left before ever seeing a doctor.

Wilson- $\quad$-Number of prenatal visits

Mitchell \&

Rummens, (2013)
-Provider type

-Length of stay in hospital for mother and baby
-Uninsured mothers had shorter hospital stays than insured mothers (1.7 days vs. 2.4 days) $(t=-6.110)$.

-No significant difference for baby length of stay between insured and uninsured mothers.

$-36.6 \%$ of uninsured saw a registered midwife vs. $4.0 \%$ of insured.

$-55.4 \%$ of uninsured saw an obstetrician vs. $94.1 \%$ of insured.

-Number of prenatal visits for the uninsured group was significantly lower than the insured group (mean 6.04 vs. 8.70; $t=-6.173$ )

$-6.5 \%$ of uninsured women received no prenatal care whereas $100 \%$ of insured women received prenatal care. An equal proportion saw a general practitioner (1.8\%).

-Using guidelines by the Society of Obstetricians and Gynaecologists of Canada, more than half $(53.7 \%)$ of the uninsured women received inadequate prenatal care in comparison to one-in-five (19.6\%) insured women.

$-75 \%$ of insured women had a Pap test; $95 \%$ of refugee and uninsured women had a Pap test.

-Univariate analysis: uninsured women were significantly more likely to have Pap tests compared to insured women (OR 6.65; $p<0.0001$ ).

-Multivariate analysis: when controlling for confounders (language, region of origin, year of arrival, pregnancy, and age), there was no significant differences in receiving a Pap test between the insured women and uninsured women (adjusted hazard ratio 1.312; $95 \% \mathrm{Cl}$ : 0.922-2.058).

-In the cox proportional hazard model, insurance status was significantly associated with time to first Pap test (adjusted hazard ratio=1.715; 95\% Cl: 1.156-2.545). Although uninsured patients were more likely to get a Pap test at any point in time in this model, after adjustment for all main regions of origin, rather than simply using the stratification of 


\begin{tabular}{|c|c|c|}
\hline & & $\begin{array}{l}\text { European versus non-European, this result became non-significant (adjusted hazard ratio } \\
1.312 ; 95 \% \mathrm{Cl} \text { : } 0.922 \text { to } 2.058) \text {. } \\
\text {-English speakers had a higher likelihood of having a Pap test early compared to non- } \\
\text { English speakers (adjusted hazard ratio } 0.62595 \% \text {; Cl: } 0.462-0.854 \text { ). }\end{array}$ \\
\hline $\begin{array}{l}\text { Jarvis, } \\
\text { Munoz, } \\
\text { Graves, et al., } \\
(2011)\end{array}$ & $\begin{array}{l}\text {-Routine prenatal services } \\
\text { (including blood tests, } \\
\text { obstetric ultrasound, cervical } \\
\text { swab for sexually } \\
\text { transmitted infections, Pap } \\
\text { tests and early genetic } \\
\text { screening) } \\
\text {-Postpartum services } \\
\text {-Visits with health care } \\
\text { professionals }\end{array}$ & 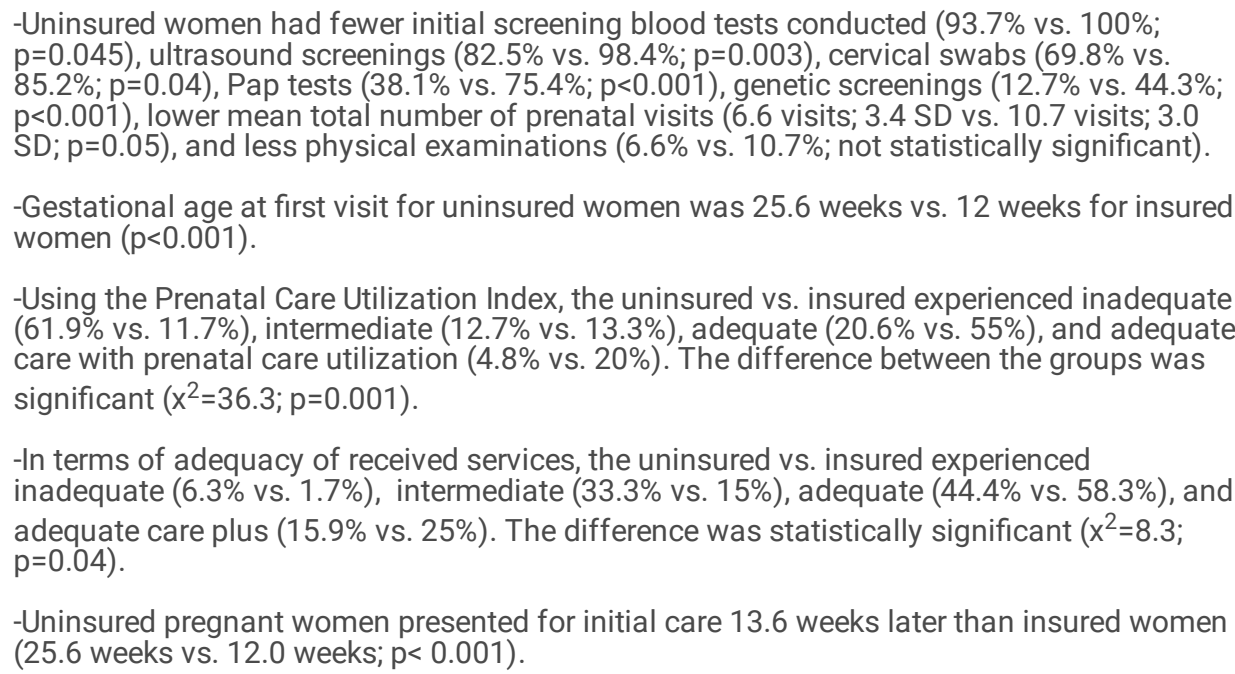 \\
\hline
\end{tabular}

$\mathrm{OR}=$ odds ratio; $\mathrm{p}=\mathrm{p}$-value; $\mathrm{x}^{2}=$ chi-squared statistic; $\mathrm{t}=\mathrm{t}$-statistic

Table IV

\section{Health outcomes of uninsured population}




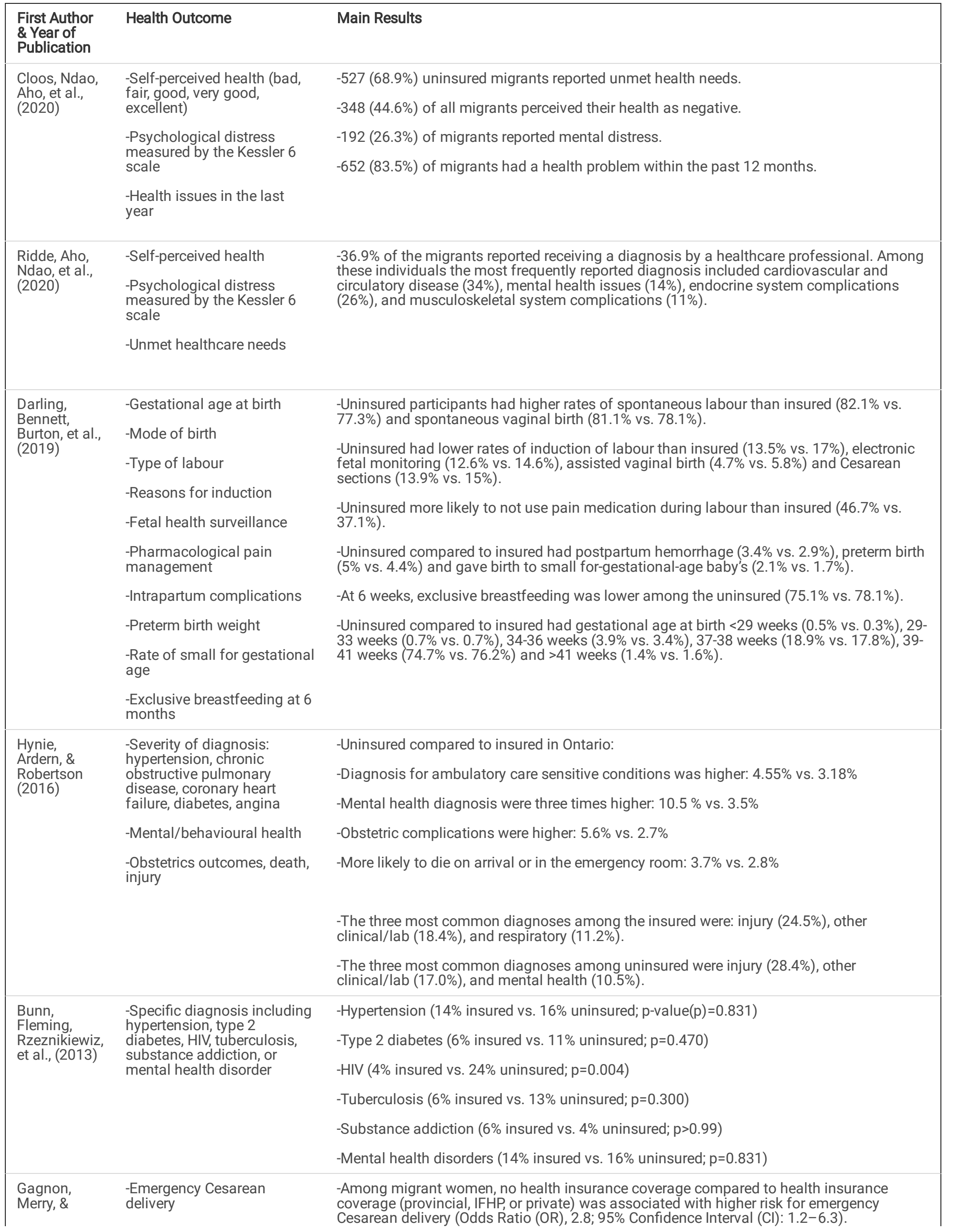




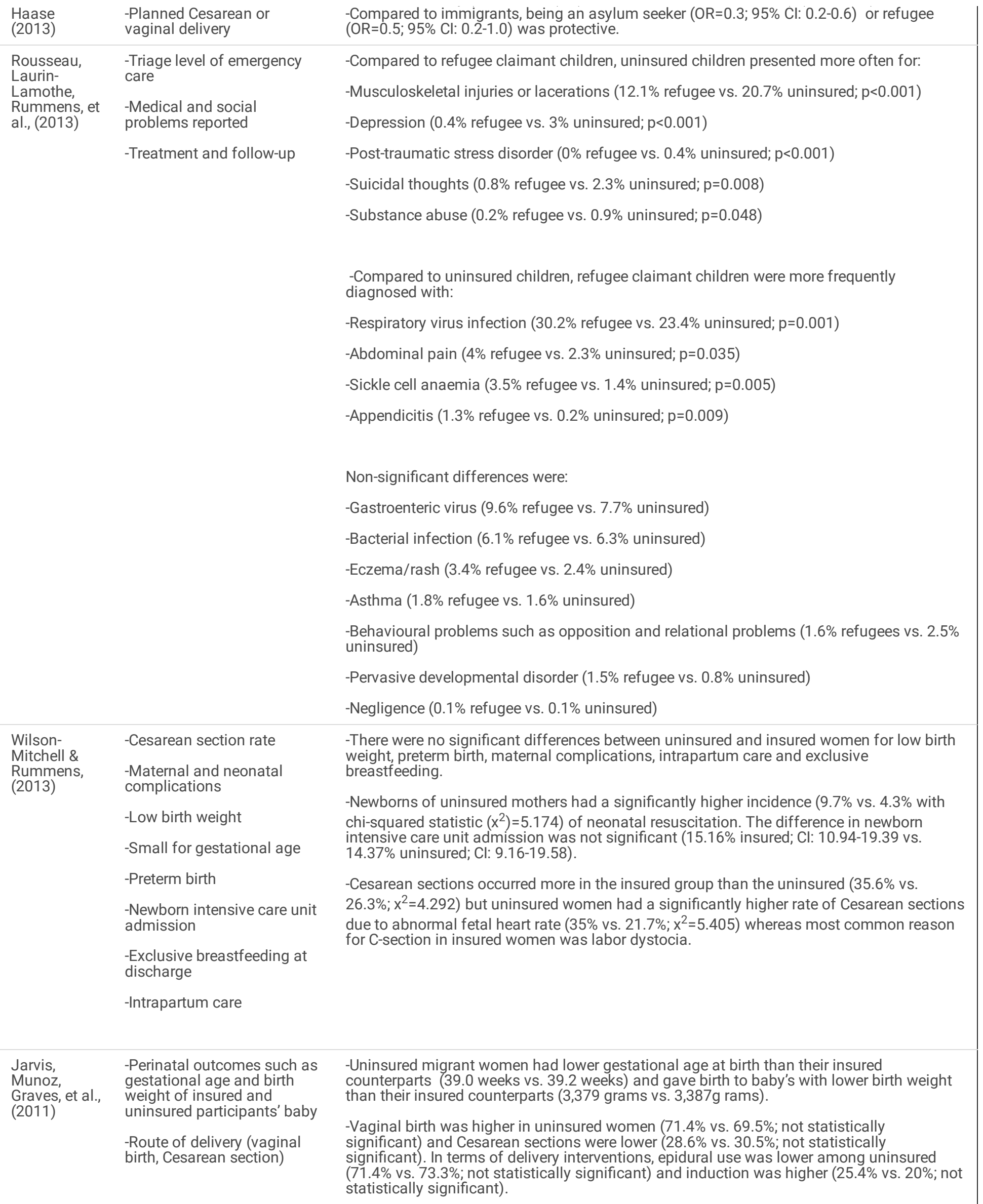

OR=odds ratio; $p=p$-value; $x^{2}=$ chi-squared statistic 
Figures

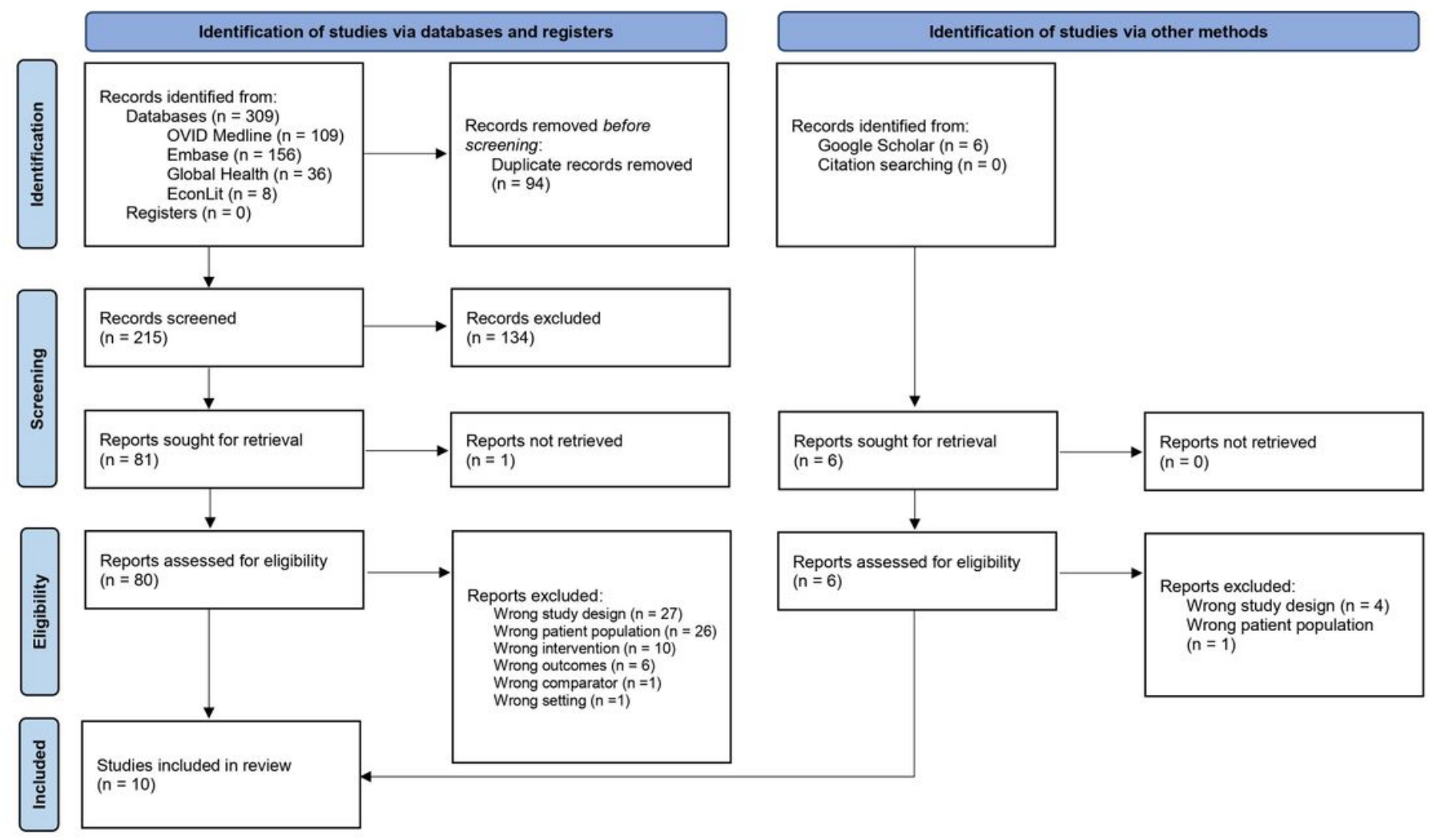

Figure 1

PRISMA representation of the search results.

\section{Supplementary Files}

This is a list of supplementary files associated with this preprint. Click to download.

- MigrantReviewSupplementaryDocument25Jan2022.docx 